\title{
Tax Reform and U.S. Economic Growth
}

\section{Citation}

Jorgenson, Dale W., and Kun-Young Yun. 1990. Tax reform and U.S. economic growth. Journal of Political Economy 98(5) Part 2: S151-S193.

\section{Published Version}

http://dx.doi.org/10.1086/261728

\section{Permanent link}

http://nrs.harvard.edu/urn-3:HUL.InstRepos:3403059

\section{Terms of Use}

This article was downloaded from Harvard University's DASH repository, and is made available under the terms and conditions applicable to Other Posted Material, as set forth at http:// nrs.harvard.edu/urn-3:HUL.InstRepos:dash.current.terms-of-use\#LAA

\section{Share Your Story}

The Harvard community has made this article openly available.

Please share how this access benefits you. Submit a story.

\section{Accessibility}




\section{| CHICAgo JOURNALS}

Tax Reform and U.S. Economic Growth

Author(s): Dale W. Jorgenson and Kun-Young Yun

Source: The Journal of Political Economy, Vol. 98, No. 5, Part 2: The Problem of Development: A Conference of the Institute for the Study of Free Enterprise Systems (Oct., 1990), pp. S151 $-\mathrm{S} 193$

Published by: The University of Chicago Press

Stable URL: http://www.jstor.org/stable/2937635

Accessed: 07/11/2009 12:49

Your use of the JSTOR archive indicates your acceptance of JSTOR's Terms and Conditions of Use, available at http://www.jstor.org/page/info/about/policies/terms.jsp. JSTOR's Terms and Conditions of Use provides, in part, that unless you have obtained prior permission, you may not download an entire issue of a journal or multiple copies of articles, and you may use content in the JSTOR archive only for your personal, non-commercial use.

Please contact the publisher regarding any further use of this work. Publisher contact information may be obtained at http://www.jstor.org/action/showPublisher?publisherCode=ucpress.

Each copy of any part of a JSTOR transmission must contain the same copyright notice that appears on the screen or printed page of such transmission.

JSTOR is a not-for-profit service that helps scholars, researchers, and students discover, use, and build upon a wide range of content in a trusted digital archive. We use information technology and tools to increase productivity and facilitate new forms of scholarship. For more information about JSTOR, please contact support@jstor.org. 


\section{Tax Reform and U.S. Economic Growth}

\section{Dale W. Jorgenson}

Harvard University

Kun-Young Yun

Yonsei University

In this paper we evaluate the impact of the Tax Reform Act of 1986 on U.S. economic growth. We first calculate effective tax rates on income from capital employed in corporate, noncorporate, and household sectors. We then project the future growth of the U.S. economy with and without the 1986 tax reform. We find that much of the potential gain in welfare was dissipated through failure to index the income tax base for inflation. The most promising avenue for future reform is to include income from household assets in the tax base, while reducing tax rates on business income.

\section{Introduction}

The purpose of this paper is to evaluate the impact of the Tax Reform Act of 1986 on U.S. economic growth. ${ }^{1}$ Major tax legislation such as the 1986 tax act can produce substantial alterations in the rate of capital accumulation and the allocation of capital among sectors and types of assets. An assessment of the impact of tax reform depends not only on the changes in tax policy but also on the elasticities of substitution along all the relevant margins. The intertemporal margin, involving the allocation of resources between present and future

\footnotetext{
${ }^{1}$ A detailed description of the Tax Reform Act of 1986 is given by the Joint Committee on Taxation (1986). The economic impact of the 1986 tax reform has been analyzed by the Office of Tax Analysis of the U.S. Department of the Treasury (1987) and in the symposium edited by Aaron (1987).
} 
consumption, is essential to the evaluation of the consequences of a tax reform involving changes in the treatment of income from capital. We conclude that a fully dynamic model of the U.S. economy is required in assessing the impact of the tax reform on economic welfare.

Harberger $(1962,1966)$ has argued that the U.S. tax system leads to a loss in efficiency since it fails to impose a uniform tax rate on income from capital in competing economic activities. There have been wide gaps between the rates of return on investment before and after taxes for assets employed in different sectors and differing in durability. However, the efficient use of capital requires a uniform tax rate only under the restrictive assumption that the allocation of capital is separable from the allocation of other resources in production and consumption. In a more general setting, uniform treatment of income from capital is neither necessary nor sufficient for efficient resource allocation. $^{2}$

Harberger's analysis of the impact of tax policy on the efficiency of capital allocation is limited to the allocation of a given capital stock. ${ }^{3}$ However, saving behavior may be affected by changes in tax policy, so that the capital stock must be determined endogenously in order to assess the economic impact of tax reform. ${ }^{4}$ In addition, the notion of efficient resource allocation must be extended to encompass intertemporal allocation. The elimination of tax distortions in the intertemporal allocation of resources requires that income from capital should not be taxed at all. Taxes on capital income could be replaced by taxes on labor income. Alternatively, income taxes could be replaced by taxes on consumption. ${ }^{5}$

The argument for eliminating capital income taxes ignores the fact that distortions in resource allocation resulting from these taxes must be replaced by other tax-induced distortions. For example, the taxa-

\footnotetext{
${ }^{2}$ For example, in Sec. IV below we find that the equalization of tax rates on corporate and noncorporate capital considered by Harberger (1966) actually reduces efficiency. However, we show that symmetrical tax treatment of income from business and household assets is a very promising avenue for future reform.

${ }^{3}$ An alternative to the Harberger model, which focuses on the incidence of the corporate income tax, is presented by Gravelle and Kotlikoff (1989). Harberger's general equilibrium approach to the analysis of tax policy has been greatly further developed by Ballard et al. (1985). The economic impact of the Tax Reform Act of 1986 has been analyzed, with an extension of this model, by Fullerton, Henderson, and Mackie (1987). A recent survey of the literature on applied general equilibrium models for tax policy analysis is provided by Whalley (1988).

${ }^{4}$ The literature on the effect of taxation on saving is reviewed by Summers (1984) and Sandmo (1985). The impact of the Tax Reform Act of 1986 on saving behavior is analyzed by Hausman and Poterba (1987).

${ }^{5}$ Proposals for the implementation of a consumption tax in the United States are discussed by the U.S. Department of the Treasury (1977), Hall and Rabushka (1983), and Bradford (1986). Arguments against a consumption tax are presented by the U.S. Department of the Treasury (1984, vol. 3).
} 
tion of labor income has important implications for economic efficiency through its effects on the choice between labor and leisure. Labor income accounts for roughly 60 percent of U.S. private national income and a very substantial proportion of U.S. tax revenues. It is well established that, even though the price elasticity of labor supply is very low, there is a substantial substitution effect that is similar in magnitude but opposite in sign to the income effect of a change in the wage rate. ${ }^{6}$ It is the substitution effect, not the total price effect, that is relevant to the impact of a tax on labor income on economic efficiency.

In order to evaluate the economic impact of the 1986 tax reform, we employ a dynamic general equilibrium model. This model provides a highly schematic representation of the U.S. economy. A single representative producer employs capital and labor services to produce outputs of consumption and investment goods. By modeling the substitution between consumption and investment goods in production, we are able to introduce costs of adjustment in the response of investment to changes in tax policy. We have simplified the representation of technology in the model by introducing a single stock of capital at each point of time. This capital is perfectly malleable and is allocated so as to equalize after-tax rates of return to equity in the corporate, noncorporate, and household sectors.

Our model also incorporates a representative consumer that supplies labor services, demands consumption goods, and makes choices between consumption and saving. This model of consumer behavior is based on an intertemporally additive utility function that depends on levels of full consumption in all time periods. Full consumption is an aggregate of consumption goods, household capital services, and leisure. To simplify the representation of preferences, we endow the representative consumer with an infinite lifetime and perfect foresight about future prices. We have fitted econometric models of producer and consumer behavior to data for the U.S. economy covering the period $1947-86 .^{7}$

The government sector of the U.S. economy raises revenues through taxes on income from capital and labor services. Corporate capital income is taxed at both corporate and individual levels, non-

${ }^{6}$ The elasticity of labor supply and its implications for tax policy are discussed by Hausman $(1981,1985)$. The impact of the Tax Reform Act of 1986 on labor supply is analyzed by Hausman and Poterba (1987).

${ }^{7}$ See Jorgenson and Yun (1986a) for a discussion of the model and Jorgenson and Yun $(1986 b)$ for an application to earlier changes in tax policy. The results presented in these papers are based on econometric models fitted to data covering the period 195580. Alternative approaches to dynamic general equilibrium modeling of U.S. tax policy are presented by Auerbach and Kotlikoff (1987) and Goulder and Summers (1989). 
corporate capital income is taxed only at the individual level, and household capital income is not taxed at either level. In addition, the government sector imposes sales taxes on the production of consumption and investment goods and property taxes on assets held by the business and household sectors. Taxes insert wedges between demand and supply prices for investment and consumption goods and for capital and labor services. These tax wedges distort private decisions and lead to losses in efficiency.

In our model the equilibrium of the U.S. economy is characterized by an intertemporal price system that clears the markets for all four commodity groups included in the model: labor and capital services and consumption and investment goods. Equilibrium at each point of time links the past and the future through markets for investment goods and capital services. Assets are accumulated as a result of past investments, while the prices of assets must equal the present values of future capital services. The time path of consumption must satisfy the conditions for intertemporal optimality of the household sector under perfect foresight. ${ }^{8}$ Similarly, the time path of investment must satisfy requirements for the accumulation of assets by both business and household sectors.

In order to evaluate alternative tax policies, we first consider the intertemporal equilibrium associated with each policy. Under perfect foresight there is a unique transition path to balanced growth equilibrium for any tax policy and any initial level of capital. The growth path of the U.S. economy consists of a plan for consumption of goods and leisure at every point of time by the representative consumer and a plan for production of investment and consumption goods from capital and labor services at every point of time by the representative producer. These plans are brought into consistency by the intertemporal price system.

Associated with each tax policy and the corresponding intertemporal equilibrium is a level of welfare for the representative consumer. This level of welfare can be interpreted as a measure of economic efficiency corresponding to the potential level of welfare for society as a whole. The actual level of welfare also depends on the distribution of welfare among consuming units. To evaluate changes in tax policy in terms of efficiency, we translate changes in potential welfare into an equivalent variation in private national wealth. We first consider the time path of the price of full consumption associated with current tax policy. We then evaluate the difference in wealth required to attain levels of potential welfare before and after the change in tax policy at prices prevailing before the change.

\footnotetext{
${ }^{8}$ Perfect foresight models of tax incidence have been presented by Hall (1971), Chamley (1981), Judd (1987), Sinn (1987), and many others.
} 
This paper is organized as follows. In Section II, we summarize the 1986 tax reform in terms of changes in tax rates, the treatment of deductions from income for tax purposes, the availability of tax credits, and provisions for indexing taxable income for inflation. We also summarize proposals for tax reform that figured prominently in the debate leading up to the 1986 tax act. We consider proposals advanced by the Department of the Treasury and by President Ronald Reagan in detail, since these proposals were instrumental in shaping the final legislation. The starting point for our discussion of the alternative proposals is the tax law in existence prior to the 1986 reform. A number of important features of the pre-existing tax law can be traced to tax reforms in the early $1980 \mathrm{~s}$.

In Section III, we analyze the tax burdens on capital income under four alternative tax policy regimes: the tax law in existence before the 1986 tax reform, the Treasury proposal, the president's proposal, and the Tax Reform Act of 1986. We utilize the concept of an effective tax rate, which summarizes statutory tax rates and provisions of tax law that affect the definition of taxable income. We also employ the notion of a tax wedge, defined in terms of differences in tax burdens imposed on different forms of income. Tax wedges represent gaps between the marginal products of different types of assets. These gaps are useful indicators of the likely impact of substitutions among different kinds of capital induced by changes in tax policy.

In Section IV of the paper, we analyze the impact of each of the alternative tax policies on U.S. economic growth. We evaluate the effects of changes in tax policy on economic efficiency by measuring the corresponding changes in potential economic welfare. The reference level of welfare, which serves as the basis of comparison among alternative tax policies, is the level attainable by the U.S. economy under the tax law in effect prior to the 1986 tax reform. We also analyze losses in efficiency associated with tax wedges among different kinds of capital income. These tax wedges are the consequences of the corporate and personal income taxes, property taxes, and sales taxes on investment goods.

Section $V$ provides a summary of the paper and presents our main conclusions. We find that much of the potential gain in welfare from the 1986 tax reform was dissipated through failure to index the income tax base for inflation. At rates of inflation near zero the loss is not substantial. However, at moderate rates of inflation, such as those prevailing for the past decade, the loss is highly significant. Second, the greatest welfare gains would have resulted from incorporating the income from household assets into the tax base, while reducing tax rates on income from business assets. The potential welfare gains from an income-based tax system, reconstructed along these lines, would have exceeded those from a consumption-based system. 


\section{Tax Reform}

When the Reagan administration took office in 1981, there was widespread concern about the slowdown in U.S. economic growth. Tax reform proposals by the administration received overwhelming support from the Congress with the enactment of the Economic Recovery Tax Act of $1981 .^{9}$ The 1981 tax act combined sizable enhancements in investment incentives with substantial reductions in statutory tax rates for individuals and corporations. These reductions created the prospect of rising federal deficits. Only one year later the Congress passed the Tax Equity and Fiscal Responsibility Act of 1982, which repealed the provisions of the 1981 act for phasing in a more accelerated cost recovery system for property placed in service after 1985 and reduced the capital cost to be amortized over the lifetime of an asset.

The tax reforms of the early 1980s substantially reduced the burden of taxation on capital income. However, these reforms also introduced important nonneutralities in the taxation of income from different sources. Differences in the tax treatment of different types of assets gave rise to concerns in Congress about the fairness of the tax system and the impact of tax-induced distortions on the efficiency of capital allocation. In the State of the Union Address in January 1984, President Reagan announced that he had requested a plan for further tax reform from the Department of the Treasury, setting off a lengthy debate that resulted in the enactment of the Tax Reform Act of 1986.

In describing the key features of the 1986 tax reform, we find it useful to begin with a description of the pre-existing tax law in order to provide a basis for comparison. The main provisions of the 1986 tax act went into effect on January 1, 1987. However, the investment tax credit was repealed for assets acquired after December 31, 1985. We refer to the pre-existing tax law as the tax law of 1985 since it remained in force until the end of calendar year 1985. To provide additional perspective on the objectives of the 1986 tax reform, we also characterize two alternative tax reform proposals presented by the Department of the Treasury and the president.

\section{A. The 1985 Tax Law}

We summarize the statutory tax rates under the 1985 tax law, the Treasury and the president's proposals, and the 1986 tax act in table 1. Column 1 gives average marginal tax rates for different types of

\footnotetext{
${ }^{9}$ We have analyzed the impact of the 1981 tax act on U.S. economic growth in a previous paper (Jorgenson and Yun 1986b, esp. pp. 365-70).
} 
income under the 1985 tax law for 0,6 , and 10 percent annual inflation rates. The tax rate on each type of income is a weighted average of marginal tax rates paid by taxpayers in all income tax brackets. Average tax rates on different types of income reflect differences in the distribution of each type of income over the tax brackets. We present rates for income in the form of dividends and other distributions on corporate and noncorporate equity, capital gains accruing on corporate and noncorporate equity, and interest on corporate, noncorporate, household, and government debt. ${ }^{10}$

We also give the average marginal tax rate on labor income, the average marginal tax rate on income under the corporate income tax, and the average tax rate under the individual income tax. All tax rates include taxes levied at both federal and state and local levels and take into account the deductibility of state and local taxes at the federal level. In projecting U.S. economic growth under the 1986 tax law, we take as fixed the average marginal tax rates on each type of income and the average individual income tax rate. Tax revenues received by the government are generated by applying these tax rates to streams of income generated endogenously within our model of U.S. economic growth.

We summarize the definition of income for tax purposes under the 1985 tax law in table 2. Section 1 describes the provisions for indexing the tax base for inflation. The 1985 tax law included no provisions of this type. Section 2 describes provisions for deductibility of capital income. Dividends paid were not deductible from corporate income for tax purposes under the 1985 tax law. However, 85 percent of corporate dividends received were excluded from corporate income. The inside buildup of life insurance companies was not taxed under the 1985 tax law. Household interest expenses were fully deductible from income at the personal level. Only 40 percent of capital gains were included in income for tax purposes. Finally, all state and local taxes were deductible from income for tax purposes, as indicated in section 3 of table 2.

In table 3 we present economic depreciation rates for each of 51 classes of assets distinguished in the U.S. national income and product accounts. We also give statutory rates of the investment tax credit and tax lifetimes under the 1985 tax law, the Treasury and president's proposals, and the Tax Reform Act of $1986 .{ }^{11}$ In panel 1 of table 4 we present average rates of the investment tax credit and present values of capital consumption allowances for short-lived and long-lived busi-

\footnotetext{
${ }^{10}$ These tax rates are based on detailed simulations of the Office of Tax Analysis Individual Income Tax Model presented by Cilke and Wyscarver (1987).

${ }^{11}$ The statutory rates of the investment tax credit and the tax lifetimes are based on the estimates of Fullerton, Gillette, and Mackie (1987).
} 
TABLE 1

TAX Rates

1. Average Marginal Tax Rates of Individual Capital Income

\begin{tabular}{|c|c|c|c|c|}
\hline & $\begin{array}{l}1985 \text { Law } \\
\text { (1) }\end{array}$ & $\begin{array}{l}\text { Treasury } \\
\text { Proposal } \\
\text { (2) }\end{array}$ & $\begin{array}{l}\text { President's } \\
\text { Proposal } \\
\text { (3) }\end{array}$ & $\begin{array}{c}1986 \text { Act } \\
(4)\end{array}$ \\
\hline & \multicolumn{4}{|c|}{ A. 0 Percent Inflation } \\
\hline \multicolumn{5}{|c|}{ Individual income accruing to: } \\
\hline Corporate equity & .2555 & .2261 & .2240 & .2029 \\
\hline Noncorporate equity & .2934 & .2427 & .2572 & .2494 \\
\hline \multicolumn{5}{|l|}{ Capital gains accruing to: } \\
\hline Corporate equity & .0303 & .0596 & .0325 & .0562 \\
\hline Noncorporate equity & .0293 & .0607 & .0322 & .0624 \\
\hline \multicolumn{5}{|c|}{ Interest income accruing to: } \\
\hline Corporate debt & .1533 & .1452 & .1532 & .1285 \\
\hline Noncorporate debt & .1971 & .1805 & .1912 & .1670 \\
\hline Household debt & .2717 & .2252 & .2387 & .2310 \\
\hline \multirow[t]{2}{*}{ Government debt } & .2205 & .1868 & .1970 & .1852 \\
\hline & \multicolumn{4}{|c|}{ B. 6 Percent Annual Inflation } \\
\hline \multicolumn{5}{|c|}{ Individual income accruing to: } \\
\hline Corporate equity & .2559 & .2261 & .2240 & .2033 \\
\hline Noncorporate equity & .2934 & .2427 & .2572 & .2494 \\
\hline \multicolumn{5}{|l|}{ Capital gains accruing to: } \\
\hline Corporate equity & .0303 & .0596 & .0600 & .0562 \\
\hline Noncorporate equity & .0293 & .0607 & .0643 & .0624 \\
\hline \multicolumn{5}{|c|}{ Interest income accruing to: } \\
\hline Corporate debt & .1730 & .1452 & .1532 & .1434 \\
\hline Noncorporate debt & .2151 & .1805 & .1912 & .1807 \\
\hline Household debt & .2722 & .2252 & .2387 & .2314 \\
\hline \multirow[t]{2}{*}{ Government debt } & .2260 & .1868 & .1970 & .1894 \\
\hline & \multicolumn{4}{|c|}{ C. 10 Percent Annual Inflation } \\
\hline \multicolumn{5}{|c|}{ Individual income accruing to: } \\
\hline Corporate equity & .2560 & .2261 & .2240 & .2034 \\
\hline Noncorporate equity & .2934 & .2427 & .2572 & .2494 \\
\hline \multicolumn{5}{|l|}{ Capital gains accruing to: } \\
\hline Corporate equity & .0303 & .0596 & .0600 & .0562 \\
\hline Noncorporate equity & .0293 & .0607 & .0643 & .0624 \\
\hline \multicolumn{5}{|c|}{ Interest income accruing to: } \\
\hline Corporate debt & .1806 & .1452 & .1532 & .1492 \\
\hline Noncorporate debt & .2222 & .1805 & .1912 & .1861 \\
\hline Household debt & .2724 & .2252 & .2387 & .2315 \\
\hline Government debt & .2282 & .1868 & .1970 & .1910 \\
\hline
\end{tabular}


TABLE 1 (Continued)

2. Marginal Tax Rates of Labor Income, Corporate Income, and Average Personal Tax Rates

\begin{tabular}{lcccc}
\hline \hline & $\begin{array}{c}1985 \text { Law } \\
(1)\end{array}$ & $\begin{array}{c}\text { Treasury } \\
\text { Proposal } \\
(2)\end{array}$ & $\begin{array}{c}\text { President's } \\
\text { Proposal } \\
(3)\end{array}$ & $\begin{array}{c}1986 \text { Act } \\
(4)\end{array}$ \\
\hline Labor income & .2967 & .2512 & .2536 & .2517 \\
Corporate income* $_{\text {Individual income }^{\dagger}}^{.5084}$ & .4006 & .4006 & .3847 \\
\hline
\end{tabular}

3. Tax Rates Held Constant across the Alternative Tax Policies

\begin{tabular}{ll}
\hline \hline Property tax rate: & \\
Corporate assets & .0100 \\
Noncorporate assets & .0096 \\
Household assets & .0100 \\
Sales tax rate: & .0579 \\
$\quad$ Consumption goods & .0579 \\
Investment goods & .0229 \\
Personal nontax rate & .0006 \\
Effective rate of wealth taxation & \\
\hline \multicolumn{2}{l}{ Nore.-Individual nncome accruing to household equity is equal to income accruing to noncorporate equity. } \\
Capital gains accruing to household equity are equal to zero. \\
* Includes federal plus state and local taxes. \\
The Treasury proposal, the president's proposal, and the 1986 Tax Reform Act are assumed to reduce the \\
average tax rate of individual income by 8.5 percent, 7.0 percent, and 6.2 percent, respectively.
\end{tabular}

ness assets under the 1985 tax law. Short-lived assets include all types of producers' durable equipment employed in the business sector. Long-lived assets include residential and nonresidential structures, land, and inventories.

\section{B. The Treasury Proposal}

In November 1984 the Treasury Department presented a tax reform plan that became known as the Treasury proposal. A principal objective of the Treasury plan was to reduce statutory tax rates at both individual and corporate levels. However, the Treasury plan was intended to be "revenue neutral," that is, to produce the same revenue as the existing tax system. ${ }^{12}$ Lower statutory tax rates were to be offset by eliminating a wide range of tax preferences, greatly broadening the tax base. In addition, the plan had the objective of introducing

${ }^{12}$ See U.S. Department of the Treasury (1984). The Treasury plan and its relationship to the Tax Reform Act of 1986 are discussed in detail by McLure and Zodrow (1987). 
TABLE 2

Indexing and Deduction of Capital Income

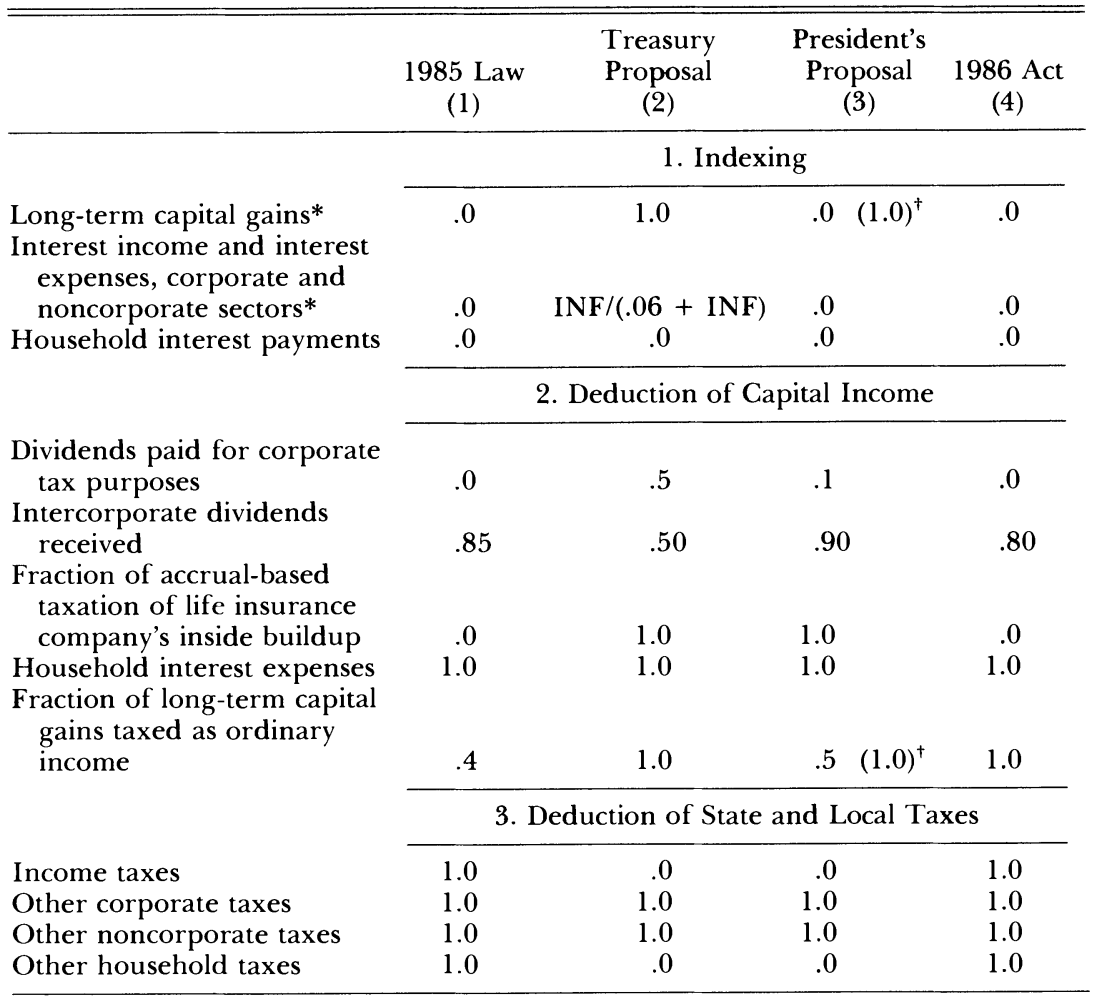

* Equals 1.0 for complete indexing.

+ Beginnıng in 1991, instead of excluding 50 percent of long-term capital gains, taxpayers have the option of 100 percent inclusion and complete indexing. We assume that if inflation is higher than 6 percent, taxpayers choose indexing.

greater neutrality in the tax treatment of different types of assets. The Treasury proposed to offset the decreased progressivity of the rate structure by curtailing tax preferences heavily used by highincome taxpayers. The tax burden for low-income earners was to be reduced through increased personal exemptions and zero bracket amounts for household heads.

Under the 1985 tax law the rate structure for the individual income tax consisted of 14 separate tax brackets, with statutory tax rates ranging from 11 to 50 percent of taxable income. Corporate income was taxed under a graduated rate structure with a top rate of 46 percent. The Treasury plan proposed to replace the 14 individual income tax brackets with three broader brackets. Individual income was to be taxed at statutory rates of 15,25 , and 35 percent. The 
reduction of statutory income tax rates was expected to lower the average marginal tax rate of individuals by 20 percent and the average individual tax rate by 8.5 percent.

Column 2 of table 1 shows the effects of the Treasury plan on average marginal tax rates. Under the central assumption of 6 percent inflation, the average marginal tax rate on income from equity would have been reduced by 11.6 percent-from 25.59 to 22.61 percent-and the corresponding average marginal tax rate on interest from corporate bonds would have been reduced by 16.1 percentfrom 17.30 to 14.52 percent. Finally, the average marginal tax rate on labor income would have been reduced by 15.3 percent-from 29.67 to 25.12 percent. These reductions in average marginal tax rates would have been offset by broadening the definition of taxable income at both individual and corporate levels in order to achieve revenue neutrality.

Under the Treasury proposal the tax base would have been broadened by wholesale elimination of tax preferences for individuals and corporations. For example, the deduction for state and local income taxes would have been repealed and other state and local taxes would have been deductible only to the extent that they were incurred in income-generating activity, as indicated in table 2. Property taxes on owner-occupied residential real estate would not have been deductible. Other proposed changes included the taxation of unemployment compensation, curtailment of the tax deductions for mortgage and other personal interest expenses, elimination of accelerated capital cost recovery, abolition of the investment tax credit, taxation of interest on private-purpose municipal bonds, accrual basis taxation of earnings on life insurance policies, recovery of intangible drilling costs in the production of petroleum and natural gas through amortization rather than immediate expensing, and many others.

The Treasury proposal included extensive provisions for indexing income and deductions from income for tax purposes for inflation. This proposal would have retained the indexing of tax brackets, personal exemptions, and zero bracket amounts from the 1981 tax act to prevent the upward creep of tax brackets as a consequence of inflation. In addition, the proposal would have indexed capital gains, interest expenses, interest income, first in, first out (FIFO) inventory accounting, and capital cost recovery. ${ }^{13}$ Prior to the tax reform of

\footnotetext{
${ }^{13}$ Deduction of mortgage and other personal interest would not have been indexed under the Treasury proposal. Indexing of interest income and interest expenses would have been based on the assumptions that the real interest rate is constant at 6 percent per year and that inflation raises the rate of inflation point for point. To the extent that the real rate of interest deviates from 6 percent, the indexing would have been incomplete.
} 


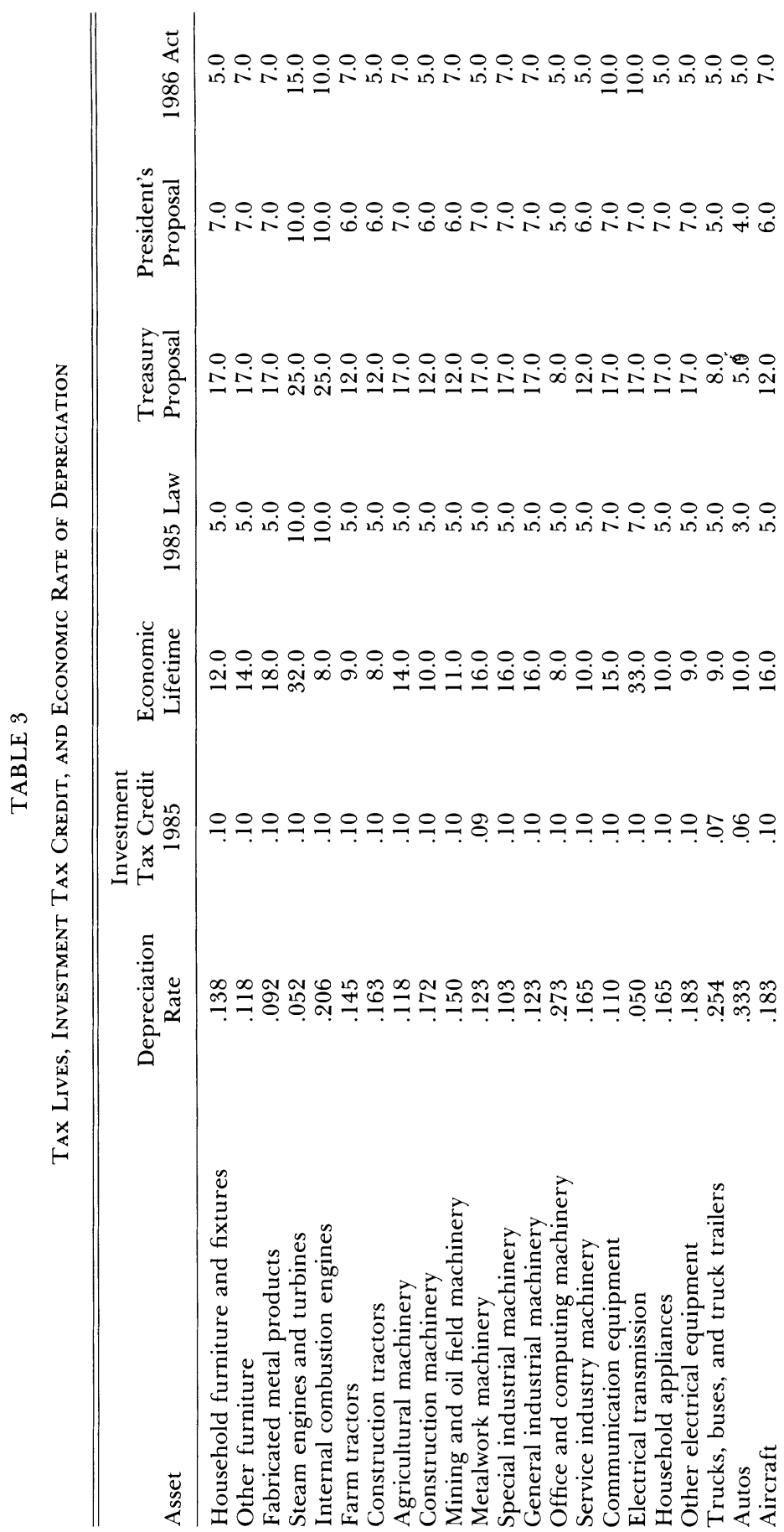

S 162 


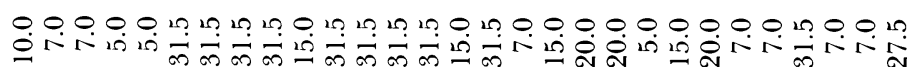

00000000000000000000000000000

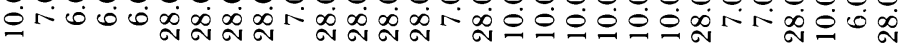

0.00000000000000000000000000 ฟै

0.00000000000000000000000000 10

0.0000000000000000000000000

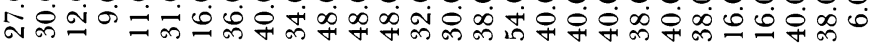

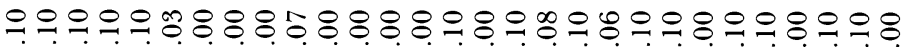

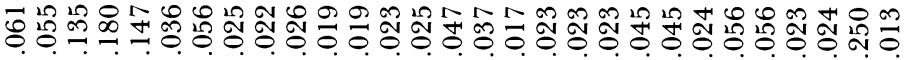

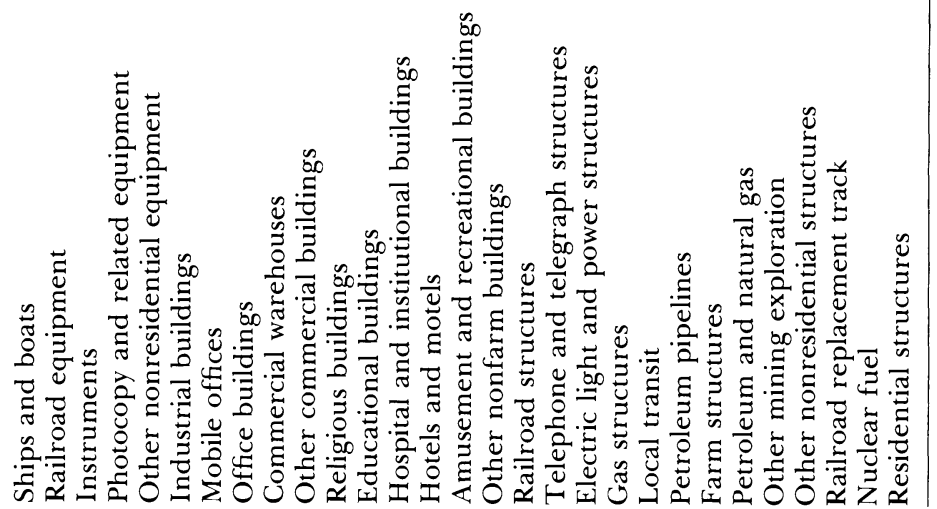


TABLE 4

Investment Tax Credit and Tax Deduction of Depreciation Allowances

\begin{tabular}{|c|c|c|c|c|}
\hline \multirow{2}{*}{$\begin{array}{l}\text { ANNUAL Rate } \\
\text { Of Inflation }\end{array}$} & \multicolumn{2}{|c|}{ CoRPorate } & \multicolumn{2}{|c|}{ NONCORPORATE } \\
\hline & Short & Long & Short & Long \\
\hline \multicolumn{5}{|c|}{ 1. $1985 \mathrm{LAW}$} \\
\hline & \multicolumn{4}{|c|}{ A. Investment Tax Credit } \\
\hline 0 percent & .0945 & .0423 & .0954 & .0056 \\
\hline 6 percent & .0944 & .0426 & .0953 & .0057 \\
\hline \multirow[t]{2}{*}{10 percent } & .0944 & .0427 & .0953 & .0057 \\
\hline & \multicolumn{4}{|c|}{ B. Present Value of Capital Consumption Allowances } \\
\hline 0 percent & .9223 & .6347 & .9204 & .5529 \\
\hline 6 percent & .8755 & .5569 & .8714 & .4609 \\
\hline 10 percent & .8469 & .5156 & .8416 & .4143 \\
\hline
\end{tabular}

2. Treasury Proposal

\begin{tabular}{ccccc}
\hline & \multicolumn{4}{c}{ A. Investment Tax Credit } \\
\cline { 2 - 5 } 0 percent & .0000 & .0000 & .0000 & .0000 \\
6 percent & .0000 & .0000 & .0000 & .0000 \\
10 percent & .0000 & .0000 & .0000 & .0000 \\
\cline { 2 - 5 } & \multicolumn{3}{c}{ B. Present Value of Capital Consumption Allowances } \\
\cline { 2 - 5 } 0 percent & .8926 & .4997 & .8981 & .3960 \\
6 percent & .9194 & .5479 & .9237 & .4441 \\
10 percent & .9275 & .5647 & .9313 & .4610 \\
\hline
\end{tabular}

3. President's Proposal

\begin{tabular}{|c|c|c|c|c|}
\hline \multirow{4}{*}{$\begin{array}{l}0 \text { percent } \\
6 \text { percent } \\
10 \text { percent }\end{array}$} & \multicolumn{4}{|c|}{ A. Investment Tax Credit } \\
\hline & .0000 & .0000 & .0000 & .0000 \\
\hline & .0000 & .0000 & .0000 & .0000 \\
\hline & .0000 & .0000 & .0000 & .0000 \\
\hline & \multicolumn{4}{|c|}{ B. Present Value of Capital Consumption Allowances } \\
\hline 0 percent & .9471 & 6142 & .9490 & .4843 \\
\hline 6 percent & 1.0059 & .7320 & 1.0058 & .6487 \\
\hline 10 percent & 1.0452 & .8283 & 1.0437 & .7925 \\
\hline \multicolumn{5}{|c|}{ 4. ТAX Аст of 1986} \\
\hline & \multicolumn{4}{|c|}{ A. Investment Tax Credit } \\
\hline 0 percent & .0000 & .0000 & .0000 & .0000 \\
\hline 6 percent & .0000 & .0000 & .0000 & .0000 \\
\hline \multirow[t]{2}{*}{10 percent } & .0000 & .0000 & .0000 & .0000 \\
\hline & \multicolumn{4}{|c|}{ B. Present Value of Capital Consumption Allowances } \\
\hline 0 percent & .9472 & .5929 & .9515 & .4861 \\
\hline 6 percent & .8714 & .4626 & .8807 & .3407 \\
\hline 10 percent & .8281 & .4058 & .8397 & .2807 \\
\hline
\end{tabular}


1986, 60 percent of net capital gains were excluded from income. With the indexing of capital gains, this exclusion could no longer be justified as an adjustment for inflation and would have been eliminated.

In order to provide relief from multiple taxation of dividend income, the Treasury proposal would have allowed 50 percent of dividends to be deducted from corporate income, as defined for tax purposes. The proposal would have eliminated multiple taxation for intercorporate dividends by excluding 50 percent of dividends received by corporations from taxable income. About $40-50$ percent of corporate profits after taxes are distributed to the shareholders in the form of dividends, so that these provisions would have significantly reduced the tax burden on corporate equity. Column 2 of table 2 summarizes the key features of the Treasury proposal.

Utilization of the economic concept of income as the base for income taxation requires that capital cost recovery must coincide with economic depreciation. To achieve this objective the Treasury proposal would have classified producers' durable equipment into five categories and structures into two categories by economic lifetime. In addition, the Treasury proposal would have indexed capital cost recovery for inflation. Panels 1 and 2 of table 4 show that at a high rate of inflation, capital cost recovery under the Treasury proposal would have been more favorable than under the 1985 tax law for both shortlived and long-lived assets; the reverse is true at a low rate of inflation. ${ }^{14}$

\section{The President's Proposal}

The Treasury tax reform plan resulted in a great public outcry, especially among taxpayers whose tax liabilities would have been adversely affected by the elimination of tax preferences. However, the rate reductions in the proposal attracted widespread approval and considerable public support. The Reagan administration did not endorse the Treasury plan, but set the Treasury staff to work on a revised proposal, duly delivered in May $1985 .{ }^{15}$ The second Treasury tax reform plan was endorsed by the administration and became known as the president's proposal.

The president's proposal would have followed the Treasury pro-

\footnotetext{
${ }^{14}$ In this calculation, we have assumed that the inflation rate increases the nominal interest rate point for point. Thus the after-tax real interest rate would have declined with inflation and the present value of capital consumption allowances would have increased with inflation under the Treasury proposal.

${ }^{15}$ The provisions of the Treasury proposal, the president's proposal, and the 1985 tax law are compared in U.S. Department of the Treasury (1985, pp. 26-30, chart 18).
} 
posal by taxing individual income in only three tax brackets with statutory rates of 15,25 , and 35 percent. The president's proposal would also have raised personal exemptions and zero bracket amounts in order to compensate low-income taxpayers for the loss in progressivity of the tax structure. The president's proposal would have maintained the favorable treatment of long-term capital gains under the 1985 tax law but would have reduced the proportion of capital gains excluded from income from 60 to 50 percent. In addition, beginning in 1991, taxpayers would have had the option of electing exclusion of 50 percent of capital gains from income for tax purposes or 100 percent inclusion of capital gains with complete indexing.

Under the president's proposal the corporate tax rate would have been graduated up to a top rate of 33 percent and corporate capital gains would have been taxed at a lower rate of 28 percent, as under the 1985 tax law. Column 3 of table 1 shows the impact of the proposal on average marginal tax rates. These changes would have lowered the average marginal tax rates at the individual level by 19 percent and the average individual tax rate by 7 percent. We find that average marginal tax rates under the Treasury and president's proposals are similar, except that the tax rates on interest and labor income would have been slightly higher under the president's proposal. $^{16}$

Like the Treasury proposal, the president's proposal was intended to produce the same tax revenue as the 1985 tax law. In order to offset the sharply lower statutory tax rates, the tax base would have been broadened by curtailing or eliminating tax preferences at both individual and corporate levels. In addition, many preferences favoring high-income taxpayers would have been limited or abolished on grounds of fairness. Important changes in the list of tax preferences would have included the repeal of the investment tax credit, repeal of the deductibility of state and local income taxes, and accrual-based taxation of earnings on life insurance policies, as indicated in table 2.

Unlike the Treasury proposal, however, the president's proposal would not have indexed interest income and expenses. When combined with the option of indexing capital gains, this feature of the proposal would have reduced the cost of capital for projects with debt financing. Another implication of the deduction of nominal interest expenses is apparent in panel 3 of table 4 . The present value of capital consumption allowances for short-lived assets is slightly greater than

\footnotetext{
${ }^{16}$ In table 1 we assume that the taxpayers would elect to be taxed on real capital gains when inflation is 0 percent and 50 percent of nominal capital gains when inflation is 6 or 10 percent.
} 
unity when inflation is 6 or 10 percent per year since the after-tax real interest rate becomes negative above a certain inflation rate. ${ }^{17}$ The present value for long-lived assets in panel 3 of table 4 is smaller than unity only because this category includes land and inventories as well as depreciable assets.

In order to alleviate multiple taxation of income from corporate equity, the president's proposal would have allowed a deduction of 10 percent of dividends paid from corporate income. Double taxation of intercorporate dividends would have been eliminated by excluding 90 percent of dividends received by corporations from taxable income. The president's proposal would have had the same effect as the Treasury proposal on the double taxation of intercorporate dividends but would have had less impact on double taxation at corporate and individual levels. Column 3 of table 2 summarizes the specific provisions of the president's proposal pertaining to taxation of income from capital.

\section{The Tax Reform Act of 1986}

The lengthy debate over tax reform was brought to a conclusion on October 22, 1986, by enactment of the Tax Reform Act of $1986 .{ }^{18}$ The main provisions of the new tax law took effect on January 1, 1987. The 1986 tax act preserved many features of the Treasury and president's proposals. The final legislation resulted in sharply lower tax rates for both individuals and corporations. The highest statutory tax rate for individuals was lowered from 50 to 28 percent. ${ }^{19}$ The corresponding rate for corporations was lowered from 46 to 34 percent. The substantial reductions in tax rates were offset by sharp cutbacks in tax preferences for both individuals and corporations.

Column 4 of table 1 shows that the tax reform reduced average marginal tax rates on various types of income in approximately the same proportion as the Treasury and president's proposals. For example, at an annual rate of inflation of 6 percent, the average mar-

\footnotetext{
${ }^{17}$ Under our assumption that an increase in the rate of inflation would result in a point-for-point increase in the nominal rate of interest, the after-tax real interest rate is $(1-T Q)\left(i_{0}+\pi\right)-\pi$, where $i_{0}$ is the real interest rate, $\pi$ is the rate of inflation, and $T Q$ is the corporate tax rate. The after-tax real interest rate is negative for an inflation rate above $(1-T Q) \imath_{0} / T Q$.

18 The Tax Reform Act of 1986 is described by the Joint Committee on Taxation (1986). The economic impact of the 1986 tax reform is discussed in detail by Musgrave (1987) and Pechman (1987). An illuminating account of the tax reform debate is presented by Birnbaum and Murray (1987).

${ }^{19}$ Because of the phaseout of the 15 percent tax bracket and the personal and dependents' exemptions for high-income taxpayers, the top marginal rate is as high as 33 percent for certain ranges of taxable income. Statutory tax rates under the 1986 tax act were higher for the transitional year 1987.
} 
ginal tax rate on individual income from equity was reduced by 20.6 percent-from 25.59 to 20.33 - and the average marginal tax rate on interest income from corporate debt was reduced by 17.1 percentfrom 17.30 to 14.34 percent. The reduction in the corporate income tax rate by 24.3 percent-from 50.84 to 38.47 percent-is even more dramatic. By contrast the average marginal tax rate on labor income was reduced by only 15.2 percent-from 29.67 to 25.17 percent.

The magnitude of the 1986 reductions in statutory tax rates for individuals and corporations is very large. It is not surprising that the base for income taxation at both individual and corporate levels had to be broadened very substantially in order to achieve revenue neutrality. Under the 1985 tax law, individuals, estates, and trusts were eligible for a 60 percent exclusion of realized net capital gains from taxable income. Corporations were taxed on capital gains at a rate of 28 percent, which was lower than the statutory corporate tax rate. Under the Tax Reform Act of 1986, the 60 percent exclusion of capital gains from taxable income at the individual level was repealed. All corporate capital gains, whether long-term or short-term, are taxed at the statutory corporate tax rate.

In spite of the reduction in the individual income tax rates, the accrual-based average marginal tax rate on capital gains increased from 3.03 percent under the 1985 tax law to 5.62 percent under the Tax Reform Act of 1986. The 1986 tax reform did not include a provision for excluding dividend payments from corporate income. In addition, the deductibility of dividends received by corporations was reduced from 85 to 80 percent. This change mainly affects the tax burden on corporate equity owned through life insurance and other insurance companies and has little impact on the overall tax burden on corporate equity.

The Tax Reform Act of 1986 also repealed the 10 percent investment tax credit for property placed in service after December 31, 1985. Since the credit was applicable mainly to investments in shortlived business assets, it had been a major source of nonneutralities in the taxation of income from different types of assets. Panel 4 of table 4 shows the differential impact of the investment tax credit on the cost of capital for short-lived and long-lived assets in the corporate and noncorporate sectors. Under the 1985 tax law the average rate of the investment tax credit in the corporate sector was 9.44 percent for short-lived assets and 4.26 percent for long-lived assets. ${ }^{20}$ The repeal

\footnotetext{
${ }^{20}$ If capital cost recovery coincides with economic depreciation, equality of effective tax rates requires that the investment tax credit must be greater for long-lived assets than for short-lived assets since short-lived assets can take the credit more frequently.
} 
of the investment tax credit has substantially reduced differences in the tax treatment of different types of assets.

Table 4 shows that the Tax Reform Act of 1986 increased the present value of capital consumption allowances for short-lived corporate assets at low or moderate rates of inflation and reduced the present value for high rates of inflation. This reflects the repeal of investment tax credit since the basis of capital cost recovery was reduced by 50 percent of the investment tax credit under the 1985 tax law. ${ }^{21}$ Capital cost recovery was made less rapid for producers' durable equipment, primarily through longer tax lifetimes. For structures the adoption of longer tax lives works in the same direction, reducing the present value of capital cost recovery.

\section{Effective Tax Rates}

The tax burden on capital income can be summarized by means of effective marginal tax rates on income from each type of assets. An effective tax rate represents the complex provisions of tax law in terms of a single ad valorem rate. This tax rate is based on the social rate of return, defined as income per dollar of capital, adjusted for inflation and depreciation but not for taxes. This social rate of return can be compared with the corresponding private rate of return, which excludes all tax liabilities at both corporate and individual levels. The effective tax rate is defined as the difference between the social and private rates of return, divided by the social rate of return. ${ }^{22}$

${ }^{21}$ If we adjust the present value of capital consumption allowances by increasing the basis for capital cost recovery to 100 percent, we find that the tax reform reduced the present value of capital cost recovery for short-lived assets. To adjust capital consumption allowances under the 1985 tax law for the effect of the provision reducing the basis of capital cost recovery by 50 percent of the investment tax credit, we can multiply the present value of capital cost recovery in table 4 under the 1985 law by $1 /(1-0.5$ ITC), where ITC is the rate of investment tax credit in the same table. For example, when the annual rate of inflation is zero, the adjusted present value of capital cost recovery for a short-lived corporate asset is $0.9223 /(1-0.5 \times 0.0944)=0.9680$, which is larger than the corresponding value, 0.9472 , under the Tax Reform Act of 1986.

${ }^{22}$ The definition of effective tax rates is discussed in more detail in our earlier paper (Jorgenson and Yun 1986 b, pp. 357-64). The effective tax rates presented below are based on the "traditional view" of corporate finance discussed by Poterba and Summers (1983). Effective tax rates at the corporate level have been compared for Germany, Sweden, the United Kingdom, and the United States for the year 1980 by King and Fullerton (1984). These effective tax rates are based on the so-called new view of corporate finance. The literature on the new view is surveyed by Auerbach (1983). Auerbach (1987) presents effective tax rates based on the new view for different types of assets within the corporate sector under the Tax Reform Act of 1986. Fullerton, Gillette, and Mackie (1987) give effective tax rates under the 1986 tax act for both views of corporate finance. These effective tax rates differ because the 1986 tax act raises the statutory tax rate on capital gains and lowers corporate and individual tax rates. 
To describe the Tax Reform Act of 1986, the pre-existing 1985 tax law, and the alternative reform proposals presented by the Treasury and the president, we utilize effective tax rates for capital income from three different legal forms of organization-corporate, noncorporate, and household-and from short-lived and long-lived assets. We also present tax wedges among different types of assets, defined as differences between social rates of return on these assets. We give tax wedges for transfers between asset categories within a sector, between sectors, and between the present and the future. We refer to these as interasset, intersectoral, and intertemporal tax wedges. The interasset and intersectoral wedges correspond to differences between marginal products of different types of assets.

In generating effective marginal tax rates and tax wedges we have employed parameters describing alternative tax laws and tax reform proposals from tables 1-3. In addition, we have set the values of parameters describing the financial structure of each sector, the corporate after-tax rate of return to corporate equity, and the rate of interest at corresponding averages for the 1967-86 period. We assume that nominal after-tax rates of return to equity are the same for all sectors and debt/equity ratios are the same for all assets with each sector. Property tax rates are set at 1986 levels. Finally, we have assumed that an increase in the rate of inflation raises the nominal rate of interest point for point. ${ }^{23}$

\section{A. The 1985 Tax Law}

We present effective tax rates under the 1985 tax law in table 5 . With a 6 percent rate of inflation, these rates were 2.4 percent for shortlived assets and 44.4 percent for long-lived assets in the corporate sector. The difference in social rates of return between the two asset classes was 4.0 percent. Transferring one dollar's worth of capital from short-lived to long-lived assets would have increased the national income in perpetuity by four cents per year with no additional investment. This is a very substantial tax wedge, comparable in magnitude to the private rate of return, suggesting that the potential gains

\footnotetext{
${ }^{23}$ The validity of our assumption that the debt/equity ratio is the same for all assets within each sector is debated by Gordon, Hines, and Summers (1987) and Gravelle (1987). Our assumption that the nominal interest rate before taxes increases point for point with inflation is consistent with the results of Summers (1983). King and Fullerton (1984) employ the alternative assumption that the nominal interest rate after taxes increases point for point with inflation. Ballentine (1987) lists a number of other important features of the 1986 tax act that are not modeled in effective tax rate calculations, such as those we present below and those given by Fullerton, Gillette, and Mackie (1987). They provide an assessment of the sensitivity of their results to these omissions (pp. 165-67).
} 


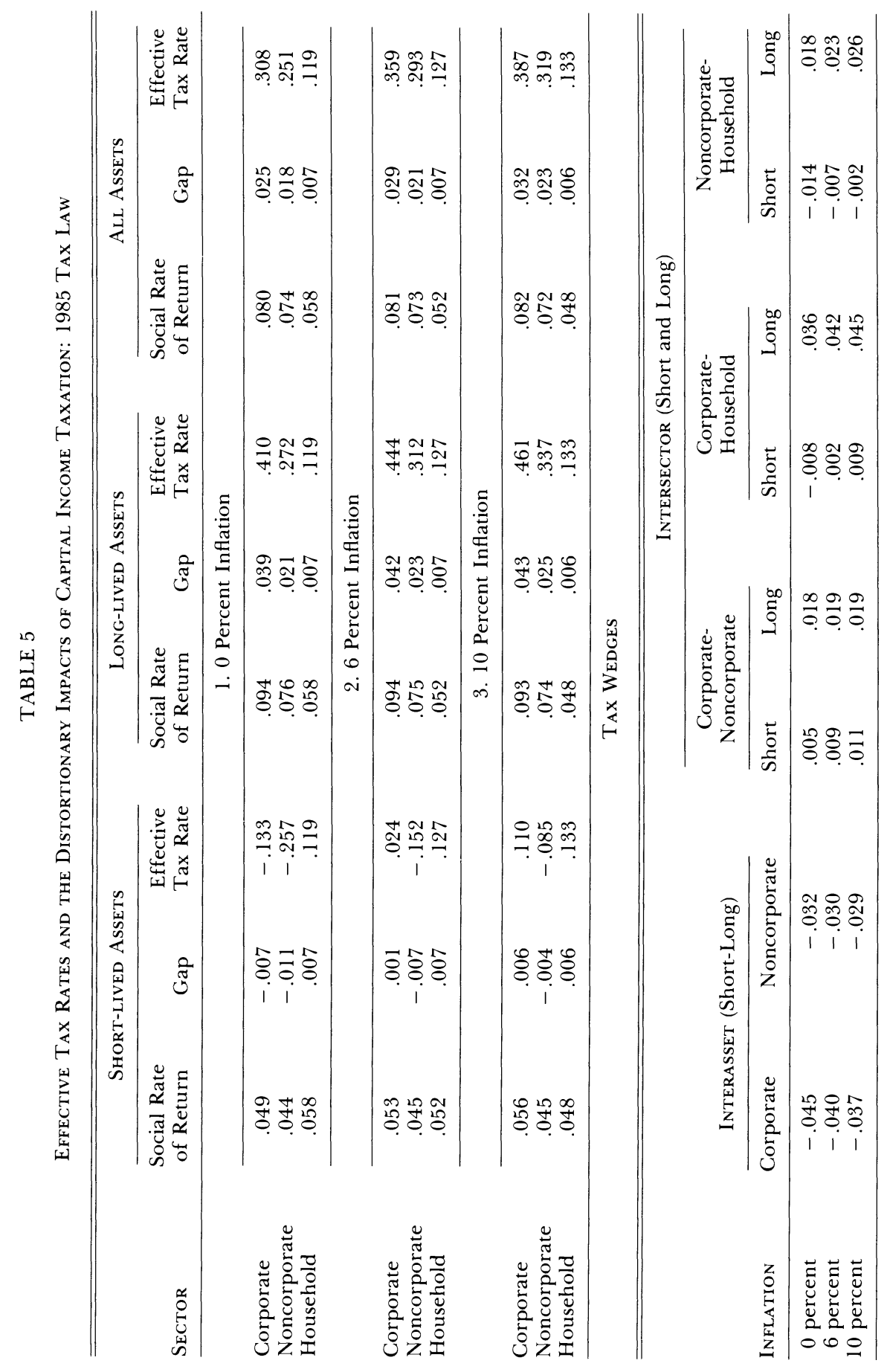


from tax reform were very large. These gains approached one dollar for each dollar transferred as a consequence of a change in tax policy.

The provisions of tax law interact with the rate of inflation in determining the tax burden on capital income. First, a higher rate of inflation reduced the present value of capital cost recovery under the 1985 tax law since cost recovery was not indexed against the impact of inflation. Second, taxation of nominal interest income, coupled with tax deductibility of nominal interest expenses, reduced the tax burden as the rate of inflation increased. For corporate and noncorporate assets the firm's marginal tax rate for the deduction of interest expenses was higher than the individual's marginal tax rate on interest income. On balance the tax burden on corporate and noncorporate assets increased with the rate of inflation. ${ }^{24}$ As the rate of inflation rose, the tax burden on short-lived assets increased faster than that on longlived assets. As a consequence the interasset tax wedge declined with the rate of inflation.

Under the 1985 tax law, assets in the noncorporate sector had lower tax burdens than corresponding assets in the corporate sector. Table 5 shows that the effective marginal tax rates for short-lived and longlived assets were -15.2 and 31.2 percent, respectively. These rates were substantially lower than the corresponding rates in the corporate sector. The interasset tax wedge between the short-lived and the long-lived assets was 3.0 percentage points. Although this tax wedge was smaller than that in the corporate sector, the interasset tax wedge in the noncorporate sector suggests substantial opportunities for potential gains from tax reform.

A striking feature of effective tax rates in the noncorporate sector under the 1985 tax law is that the effective tax rate on short-lived assets was negative. The provisions for capital cost recovery and the investment tax credit were so favorable that the tax system, in effect, provided subsidies to noncorporate investment in short-lived assets. These subsidies took the form of a "tax shelter" that could be used to reduce tax liabilities on other types of income. The effects of inflation on the tax burdens and the interasset tax wedge in the noncorporate sector were similar to those in the corporate sector. Inflation increased the tax burden on capital income and reduced the interasset tax wedge.

The value of capital services of household assets, such as the rental equivalent of owner-occupied housing or the services of consumers' durables, was not included in taxable income under the 1985 tax law.

\footnotetext{
${ }^{24}$ Another mechanism, which we do not model, is that firms using the FIFO inventory accounting method overstate their profits and hence their taxable income when inflation is positive.
} 
However, effective tax rates on household assets were affected by provisions of the individual income tax since payments for personal and mortgage interest were deductible and interest income from the debt claims on household assets was taxable. Like the assets in the corporate and noncorporate sectors, household assets were also subject to property taxes. Table 5 shows that the effective tax rate on household assets was 12.7 percent with 6 percent inflation. This rate increased slightly with inflation. Since the income from household assets was not taxable, there was no interasset tax wedge in the household sector.

Table 5 shows intersectoral tax wedges under the 1985 tax law for short-lived and long-lived assets. When the rate of inflation was 6 percent per year, the intersectoral tax wedge between the corporate and noncorporate sectors was 0.9 percent for the short-lived assets and 1.9 percent for long-lived assets. The wedges between the noncorporate and household sectors were -0.7 percent for short-lived assets and 2.3 percent for long-lived assets. The wedges between the corporate and household sectors were 0.2 percent for short-lived assets and 4.2 percent for long-lived assets. Unlike the interasset tax wedges, the intersectoral tax wedges tended to increase with the rate of inflation since the tax burden of corporate assets increased faster than that of noncorporate assets, which in turn increased faster than that of household assets.

\section{B. The Treasury Proposal}

Effective marginal tax rates on business assets under the Treasury proposal are given in table 6 . These rates are similar to those under the 1985 tax law. A comparison of tables 5 and 6 reveals that at 6 percent inflation the Treasury proposal would have slightly reduced the effective marginal tax rate from 35.9 to 35.1 percent for corporate assets and from 29.3 to 27.1 percent for noncorporate assets. Since the 1985 tax law did not index taxable income and tax deductions, the Treasury proposal would have increased the tax burden at a lower rate of inflation but would have decreased it at a higher inflation rate.

The effective marginal tax rates under the Treasury proposal reflect the combined effects of the repeal of investment tax credit, the introduction of economic depreciation, lowering of statutory tax rates, and indexing of interest income, interest expenses, and capital gains. Of the many tax policy changes in the Treasury proposal, the repeal of investment tax credit would have had the greatest impact on effective tax rates on income from capital. Since short-lived business assets received the most important benefits from the investment 


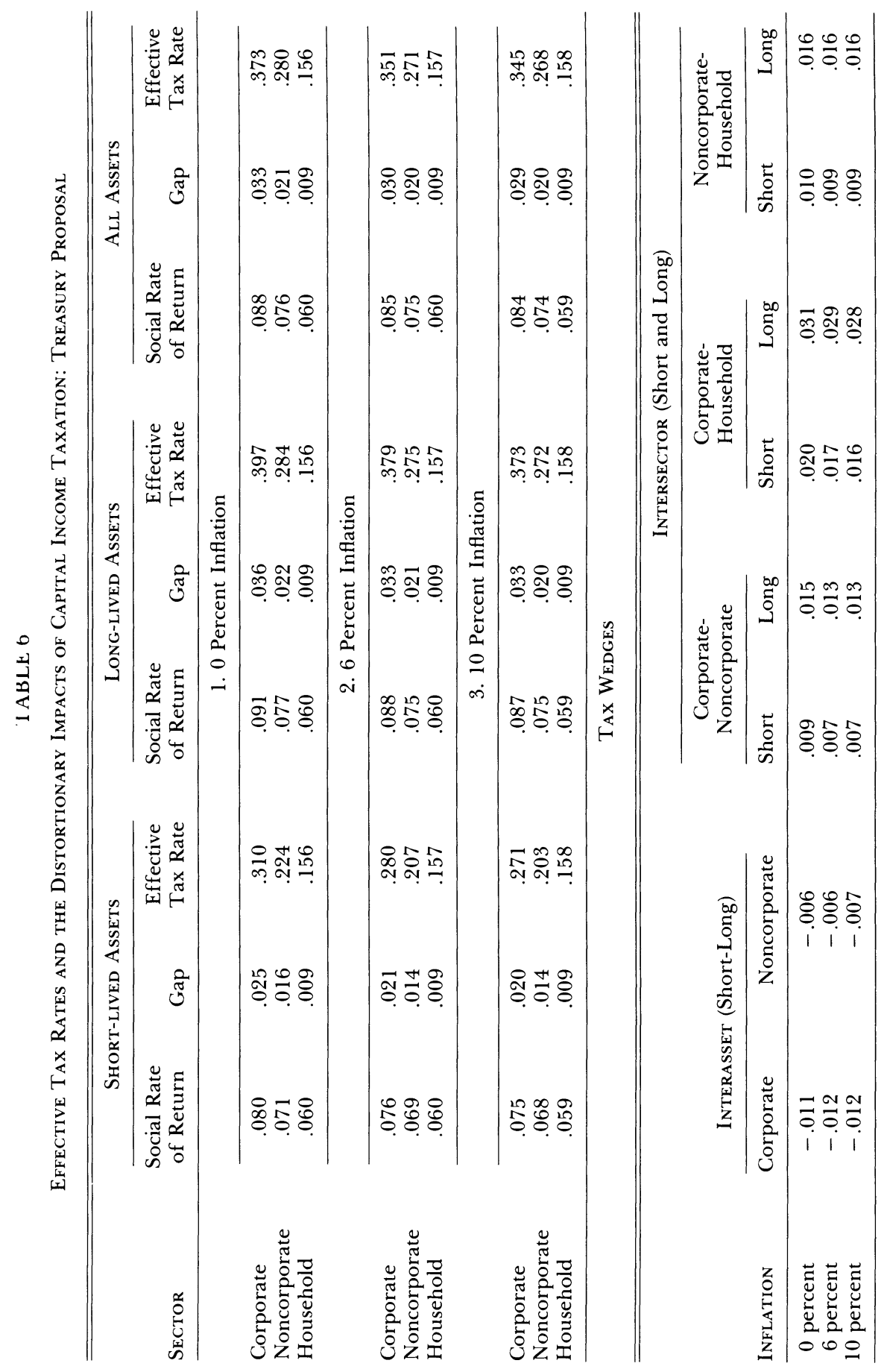


tax credit under the 1985 tax law, the increase in the tax burden on short-lived assets under the Treasury proposal would have been most marked.

The objectives of the Treasury proposal were to reduce tax wedges among different forms of investment and insulate the tax structure from the impact of inflation. We find that the Treasury proposal would have reduced interasset tax wedges substantially. Under the 1985 tax law with 6 percent inflation, the tax wedges between shortlived and long-lived assets were 4.0 percent in the corporate sector and 3.0 percent in the noncorporate sector. They would have been reduced to only 1.2 percent and 0.6 percent, respectively, under the Treasury proposal. To the extent that the welfare cost of a tax distortion increases with the tax wedge, reductions in the interasset tax wedges of this magnitude would have significantly improved the efficiency of capital allocation within each sector.

Second, the Treasury proposal would have substantially reduced the intersectoral tax wedges for long-lived assets, in part because of the elimination of property tax deductions, but would have had mixed effects for short-lived assets. The impact of the proposal on intersectoral tax wedges for short-lived assets would have depended on the rate of inflation. The Treasury proposal would have been relatively ineffective in eliminating the substantial intersectoral tax wedges for long-lived assets under the 1985 tax law since long-lived assets would have borne a heavier tax burden than the short-lived assets under the proposal. In addition, corporate assets would have been more heavily taxed than noncorporate assets, which, in turn, would have been more heavily taxed than household assets.

Third, the repeal of investment tax credit would have increased the tax burden roughly as much as the reduction of the statutory tax rates would have decreased it at a 6 percent rate of inflation. The average effective tax rate for the entire corporate sector would have changed only from 35.9 percent to 35.1 percent and the intertemporal tax wedge would have increased slightly from 2.9 percent to 3.0 percent. The effect of the repeal of investment tax credit is seen most clearly in the case of the short-lived business assets. At a 6 percent rate of inflation, the effective tax rate on short-lived corporate assets would have increased from 2.4 percent under the 1985 law to 28.0 percent under the Treasury proposal, and the intertemporal tax wedge would have increased from 0.1 percent to 2.1 percent. The pattern is reversed for long-lived assets since the intertemporal tax wedges would have been smaller under the Treasury proposal.

Finally, the Treasury proposal would have reduced the impact of inflation on the tax burden on capital income by defining taxable income to approximate economic income more closely. In fact, the tax 
burden would have declined with inflation because of incomplete indexing of interest payments. ${ }^{25}$ To the extent that interest is not completely indexed, inflation tends to increase the after-tax real interest rate and reduce the present value of capital consumption allowances, even if tax depreciation is completely indexed against inflation. On the other hand, incomplete indexing reduces the cost of debt financing. Table 6 indicates that the result of these two opposing effects would have been to reduce the marginal tax burden of capital with higher rates of inflation.

\section{The President's Proposal}

We summarize effective tax rates under the president's proposal in table 7. Overall, the effects of the president's proposal would have been similar to those of the Treasury proposal. The tax burden on income from capital would have increased at a low rate of inflation and decreased at a high rate. The interasset tax wedges in the corporate and noncorporate sectors would have been reduced; the intersectoral tax wedges of long-lived assets would also have been reduced, but effects on the tax wedges for the short-lived assets would have been mixed. However, a careful comparison of tables 6 and 7 reveals a number of subtle differences between the Treasury and president's proposals, many of which are attributable to differences in the impact of inflation on the tax system.

With no inflation the president's proposal would have been more favorable to investment since it would have retained accelerated schedules for capital cost recovery. At 6 or 10 percent inflation rates, the president's proposal would have been even more favorable to investment since the indexing of capital consumption allowances would have been coupled with the deduction of nominal interest expenses. This would have increased the present value of capital consumption allowances at higher rates of inflation. In addition, inflation would have lowered the tax burden on capital as a consequence of the tax deductibility of nominal interest expenses. The value of the resulting deductions would have been greater than the additional tax liabilities resulting from the taxation of nominal interest income at the individual level. Similar reasoning can be applied to explain the decline of the intersectoral tax wedges with inflation.

Under the 1985 tax law and the Tax Reform Act of 1986, capital cost recovery is not indexed for inflation, so that an increase in the in-

\footnotetext{
${ }^{25}$ We assume that the real interest rate is 3.57 percent as opposed to the 6 percent used in the proposal. Under our assumptions, interest income and expenses would have been incompletely indexed and inflation would have had an impact on effective tax rates.
} 


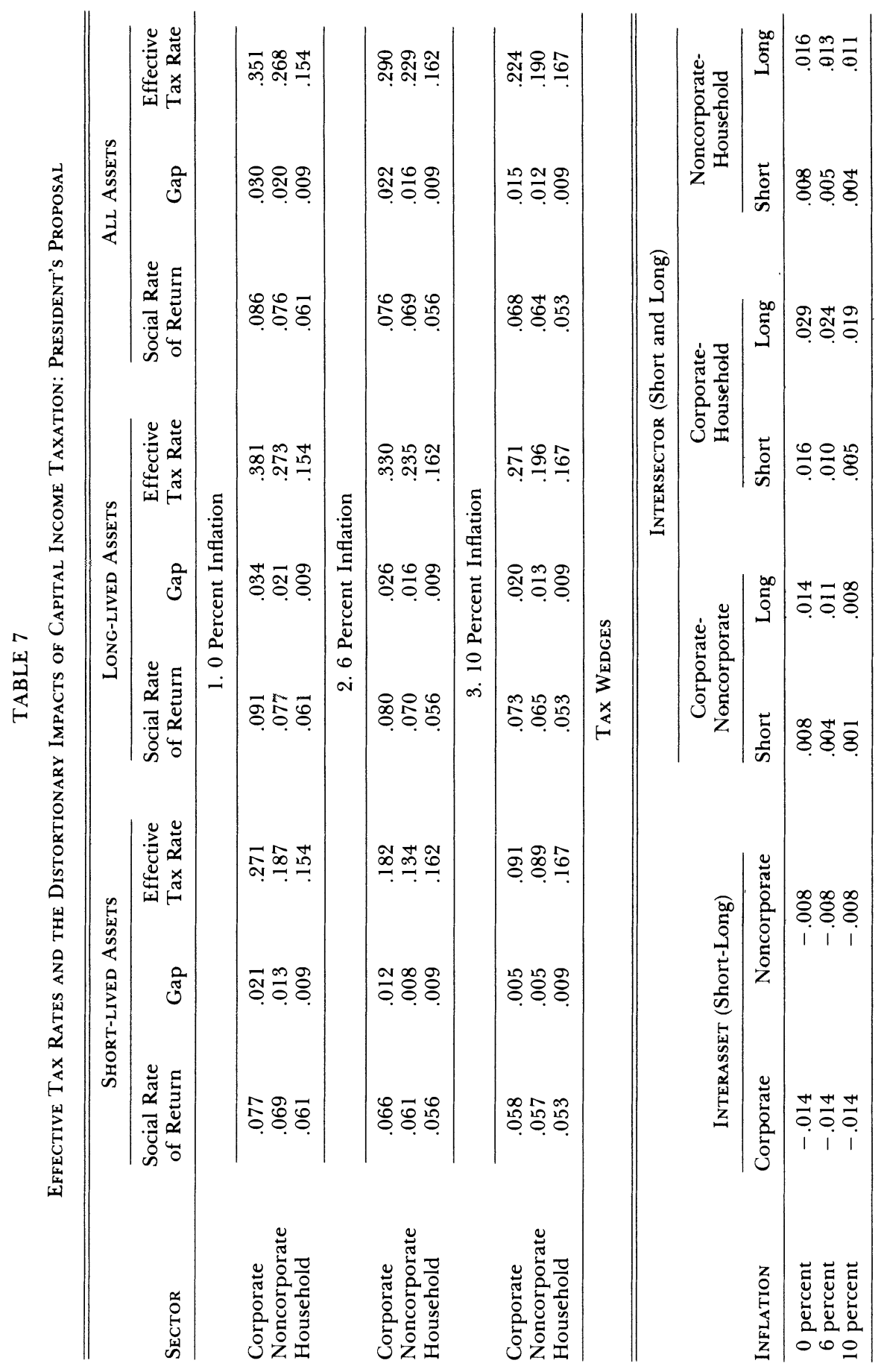


flation rate adds to the tax burden on income from capital. Under the Treasury proposal, the recovery of capital cost would have been indexed and interest would have been indexed incompletely. There would have been a slight tendency for the tax burden on capital income to decline with inflation. This tendency would have been strengthened under the president's proposal since capital cost recovery would have been indexed, while interest deductions would not. Tables 6 and 7 show that the president's proposal would have narrowed the intersectoral tax wedges relative to the Treasury proposal. By contrast the Treasury proposal would have had uniformly smaller interasset tax wedges.

\section{The Tax Reform Act of 1986}

Since the Tax Reform Act of 1986 embraced many of the ideas contained in the Treasury and president's proposals, the impact of the tax reform on effective tax rates and tax wedges is similar to that of the two proposals. Table 8 shows that the repeal of the investment tax credit more than offset the reduction in the statutory tax rates, so that the overall tax burden on income from capital is increased. Despite the acceleration of capital cost recovery and lower marginal tax rates, the impact of repeal of the investment tax credit is most evident in the increase of the tax burden on short-lived business assets. At 6 percent inflation, the Tax Reform Act of 1986 imposes an effective tax rate on short-lived assets of 38.2 percent in the corporate sector and 28.2 percent in the noncorporate sector, while the corresponding tax rates were 2.4 percent and -15.2 percent under the 1985 tax law.

For long-lived assets, effective tax rates were not much affected by tax reform. The effects of lower tax rates were approximately offset by the combined effects of the longer cost recovery period and the repeal of the investment tax credit. At 6 percent inflation, the interasset tax wedges in the corporate and noncorporate sectors are only 1.0 percent and 0.6 percent, while the corresponding figures were 4.0 percent and 3.0 percent, respectively, under the 1985 tax law. Table 8 shows that the effective tax rates on household assets were essentially unaffected by the reform since the difference between the average marginal tax rates on equity and debt claims was almost unchanged and property taxes remained the same.

Overall, the tax burden on the income from capital was increased by the 1986 tax reform. As a consequence, the intertemporal tax wedges are larger and the efficiency of intertemporal resource allocation was adversely affected. On the other hand, the interasset tax wedges were considerably reduced and the efficiency of interasset capital allocation was enhanced. At 6 percent inflation, intersectoral 


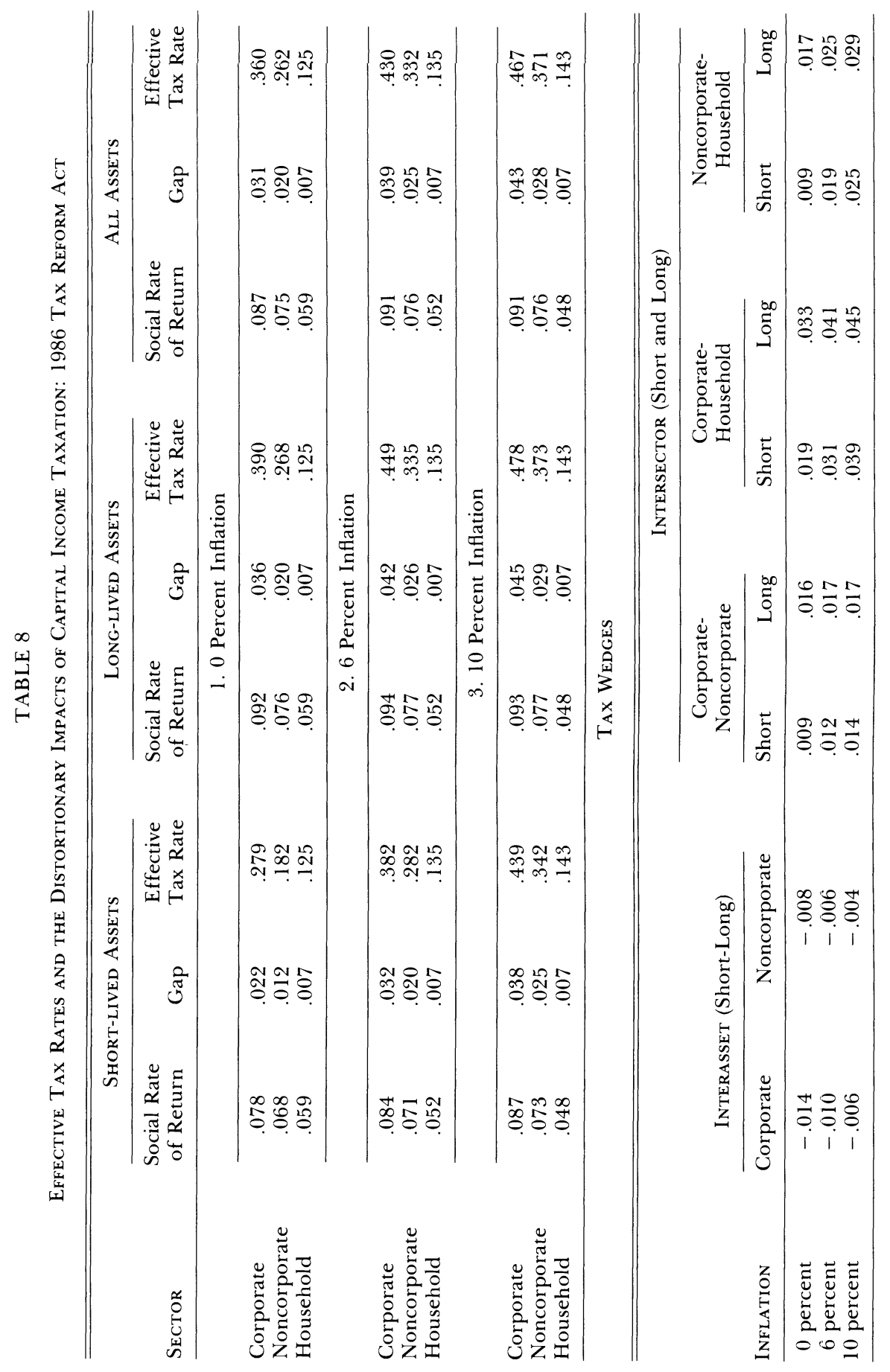


wedges were increased for short-lived assets and decreased for longlived assets.

The 1986 tax reform did not incorporate the indexing of capital income taxation provided in the Treasury proposal. The impacts of inflation on effective tax rates and tax wedges under the Tax Reform Act of 1986 are similar to those under the 1985 tax law. The tax burden on income from capital increases with inflation. Since the tax burden on short-lived assets rises faster than that on long-lived assets, interasset tax wedges decline with the rate of inflation. The tax burden on corporate assets increases faster than that on noncorporate assets, which in turn increases faster than that on household assets, so that intersectoral tax wedges increase with the rate of inflation.

\section{Economic Growth}

In this section we estimate the impact of alternative tax policies-the Treasury proposal, the president's proposal, and the Tax Reform Act of 1986-on U.S. economic growth. We evaluate the effect of each of the alternative tax reform proposals by comparing the resulting level of welfare with that attainable under the "base case" given by the 1985 tax law. Since effective tax rates and tax wedges depend on the rate of inflation, we consider three alternative rates of inflation: 0,6 , and 10 percent. In these comparisons we impose the requirement that the revenue and expenditure of the government sector are the same as those in the base case.

We consider four alternative methods for adjusting tax revenues in order to keep the budgetary position of the government sector the same as that in the base case. The first method is to increase or decrease government revenues by means of a "lump-sum" tax or subsidy. We model a lump-sum tax by altering the budget constraint facing the representative consumer. A tax results in a contraction of the budget available to the consumer and a corresponding increase in government revenue. Similarly, a subsidy expands the budget available to the consumer and decreases government revenue. A lumpsum tax or subsidy does not distort decisions in the household or business sector of the economy by altering the tax wedges facing the representative consumer or the representative producer.

We also consider three methods for adjusting government revenues that involve changes in tax-induced distortions. These include proportional adjustments to labor income taxes, sales taxes on investment and consumption goods, and taxes on income from both capital and labor. The labor income tax adjustment affects the tax rate for labor services, the sales tax adjustment affects the tax rates for consumption and investment goods, and the income tax adjustment af- 
TABLE 9

Welfare EfFEcts of TAX Reform (Billions of 1987 Dollars)

\begin{tabular}{|c|c|c|c|c|}
\hline Revenue Adjustment & $\begin{array}{c}1985 \\
\text { Tax Law }\end{array}$ & $\begin{array}{l}\text { Treasury } \\
\text { Proposal }\end{array}$ & $\begin{array}{c}\text { President's } \\
\text { Proposal }\end{array}$ & $\begin{array}{c}1986 \\
\text { Tax Act }\end{array}$ \\
\hline & \multicolumn{4}{|c|}{0 Percent Inflation } \\
\hline Lump-sum tax & 724.0 & $1,489.6$ & $1,691.4$ & $1,561.8$ \\
\hline Labor income tax & 478.2 & $1,468.8$ & $1,642.4$ & $1,565.0$ \\
\hline Sales tax & 400.3 & $1,452.9$ & $1,614.6$ & $1,558.7$ \\
\hline \multirow[t]{2}{*}{ Individual income tax } & 374.5 & $1,456.1$ & $1,619.1$ & $1,563.1$ \\
\hline & \multicolumn{4}{|c|}{6 Percent Inflation } \\
\hline Lump-sum tax & 0.0 & $1,907.6$ & $2,452.2$ & 448.4 \\
\hline Labor income tax & 0.0 & $1,711.4$ & $2,170.4$ & 746.9 \\
\hline Sales tax & 0.0 & $1,600.1$ & $2,104.9$ & 901.2 \\
\hline \multirow[t]{2}{*}{ Individual income tax } & 0.0 & $1,595.8$ & $2,007.9$ & 999.4 \\
\hline & \multicolumn{4}{|c|}{10 Percent Inflation } \\
\hline Lump-sum tax & -477.1 & $2,060.4$ & $3,015.6$ & -200.8 \\
\hline Labor income tax & -333.7 & $1,791.6$ & $2,584.7$ & 267.3 \\
\hline Sales tax & -285.2 & $1,623.5$ & $2,356.4$ & 517.0 \\
\hline Individual income tax & -221.9 & $1,604.8$ & $2,353.1$ & 748.6 \\
\hline
\end{tabular}

NoTE - The 1987 national wealth (beginning of the year) and gross national product were $\$ 15,920.2$ billion and $\$ 4,488.5$ billion.

fects the tax rates for both capital and labor services. By considering all three methods, we are able to assess the sensitivity of the welfare rankings of alternative tax policies to changes in the constraints imposed by the requirement of revenue neutrality.

\section{A. The Impact of Tax Reform}

We summarize the results of our simulations of U.S. economic growth under alternative tax policies in table 9. An important conclusion we can draw from the table is that the Treasury proposal, the president's proposal, and the Tax Reform Act of 1986 all improve potential economic welfare substantially. In our central case with 6 percent inflation and a lump-sum tax adjustment, the president's proposal would have generated a welfare gain of $\$ 2,452.2$ billion, while the Treasury proposal would have generated a gain of $\$ 1,907.6$ billion. However, the welfare gain associated with the Tax Reform Act of 1986 is only $\$ 448.4$ billion. $^{26}$

With no change in government expenditures the Tax Reform Act of 1986 results in more revenue than is necessary to keep the govern-

${ }^{26}$ These welfare gains are measured in 1987 dollars. 
ment in the same budgetary position as under the 1985 tax law. In order to leave government revenue the same under the two tax policies, tax revenues must be rebated to the household sector. Replacing the lump-sum tax adjustment with a distortionary tax adjustment lowers the rates of the distortionary taxes involved and improves the performance of the economy under the 1986 tax reform. By contrast, the Treasury and the president's proposals would have resulted in less revenue than the 1985 tax law. The welfare gains would have been smaller under the distortionary tax adjustments than under the lump-sum tax adjustment.

Another perspective on the economic impact of the alternative tax reform proposals is provided by a comparison of the welfare gains from tax reform with private national wealth. The nominal value of the U.S. private national wealth at the beginning of 1987 was $\$ 15,920.2$ billion. Making use of this figure, we estimate that the welfare gains from the Treasury and the president's proposals would have been equivalent to increases of 12.0 and 15.4 percent, respectively, of U.S. private national wealth in $1987 .{ }^{27}$ The welfare gain from the Tax Reform Act of 1986 is equivalent to an increase of only 2.8 percent of the national wealth.

Under distortionary tax adjustments the welfare gains would have been somewhat smaller for the president's proposal and slightly smaller for the Treasury proposal. The gains are substantially larger for the 1986 Tax Reform Act. However, these gains are not sensitive to the differences among the distortionary tax adjustments. ${ }^{28}$ If we consider a sales tax adjustment with a 6 percent inflation rate, the welfare gains would have been $\$ 1,600.1$ billion for the Treasury proposal and $\$ 2,104.9$ billion for the president's proposal. These gains would have totaled 10.1 and 12.3 percent of the U.S. private national wealth in 1987 . The corresponding welfare gain is $\$ 901.2$ billion for the Tax Reform Act of 1986. This is equivalent to 5.7 percent of the national wealth.

Table 9 also shows how the welfare effects of alternative tax reforms would be affected by the rate of inflation. It is useful to focus on lump-sum tax adjustments since distortionary tax adjustments result in reallocations of resources due to substitutions as well as changes in the rate of inflation. Economic welfare would have in-

\footnotetext{
${ }^{27}$ In interpreting these comparisons in terms of the U.S. private national wealth, one should bear in mind that the private national wealth includes only nonhuman wealth, while the welfare gains from tax reform accrue to the owners of nonhuman capital and also to recipients of labor income, which can be regarded as a return to human capital.

${ }^{28}$ This does not imply that the distortionary effects of the taxes used for revenue adjustments are similar. Rather it reflects the fact that the size of the required revenue adjustments is not large enough to produce sizable differences.
} 
creased with higher inflation under the Treasury and president's proposals. On the other hand, welfare declines with inflation under the 1985 tax law and the Tax Reform Act of 1986. The reason is that the tax burden on capital income would have been reduced with higher inflation under the two proposals, while inflation increases the tax burden on capital income under the 1985 tax law and Tax Reform Act of 1986.

An increase in the rate of inflation from 0 to 6 percent is sufficient to alter the welfare ranking between the Treasury proposal and the Tax Reform Act of 1986. The welfare gains from the 1986 tax reform are substantially attenuated at a 6 percent inflation rate. At a 10 percent inflation rate, these gains are further reduced. Our first conclusion is that potential gains in welfare from the 1986 reform are largely dissipated at moderate rates of inflation, such as those that have prevailed for the past decade. Insulating the U.S. tax system from the impact of inflation should retain high priority in future deliberations about tax reform.

\section{B. Alternative Approaches to Tax Reform}

We have measured the impact of the Tax Reform Act of 1986 on economic welfare, employing the 1985 tax law as a basis for comparison. We have also assessed the potential impact of the Treasury and president's tax reform proposals. We next consider alternative approaches to tax reform based on the elimination of tax wedges among different types of assets. As before, the growth path of the U.S. economy under the 1985 tax law is taken as a basis for comparison. We measure the potential gains in economic welfare from changes in tax policy by comparing the resulting levels of welfare with those corresponding to the 1985 tax law.

For the purposes of this analysis we find it useful to distinguish between atemporal and intertemporal tax wedges. The elimination of an atemporal tax wedge requires that the social rates of return on the corresponding assets are equalized within a given time period. We eliminate atemporal tax wedges among assets by equalizing the corresponding social rates of return at a weighted average of these rates of return, where stocks of assets are used as weights. More precisely, we equalize social rates of return associated with balanced growth equilibrium under the 1985 tax law, using the balanced growth proportions of assets as weights.

To model the integration of the corporate and individual income taxes, we set the social rates of return on corporate assets equal to those on the corresponding noncorporate assets. This procedure does not affect the private rates of return in the two sectors, so that effec- 
tive tax rates are not equalized between the sectors. The private rates of return on assets in different sectors differ for two reasons. The first is that debt/asset ratios differ across sectors. The second is that average marginal tax rates on individual income vary from sector to sector because of the differences in the distribution of asset ownership among taxpayers in different income tax brackets.

We consider the elimination of five sets of tax wedges: (1) interasset tax wedges within the corporate and noncorporate sectors; (2) intersectoral tax wedges between assets of the same type held in the corporate and noncorporate sectors; (3) intersectoral tax wedges among assets of the same type held in the business and household sectors, where the business sector includes both corporate and noncorporate business; (4) all atemporal tax wedges in the business sector; and (5) all atemporal tax wedges in the business and the household sectors. We also consider (6) the integration of corporate and noncorporate taxes.

Elimination of an intertemporal tax wedge requires equalizing the social and private rates of return, so that the effective tax rate on the corresponding assets is reduced to zero. We consider two possible approaches to eliminating intertemporal tax distortions. First, we consider (7) the elimination of intertemporal tax wedges resulting from income and property taxes. This leaves the sales tax on investment goods at its level in the base case while reducing the effective tax rate on capital income to zero. Second, we eliminate the tax burden on capital altogether by (8) removal of the sales tax on investment goods as well as taxes on income from capital and property taxes. These two approaches correspond to alternative implementations of consumption tax rules for the taxation of capital income.

We summarize the sums of the investment tax credit and the present value of tax deductions for capital cost recovery that result in the elimination of tax wedges among different classes of assets in table 10. Panel A represents the base case, corresponding to the 1985 tax law. Panel B represents the elimination of interasset tax wedges within the corporate and noncorporate sectors. This can be achieved by setting the sums of the investment tax credit and the present value of tax deductions for capital cost recovery at the values specified in the table. The social rates of return and the effective tax rates must be the same for short-lived and long-lived assets within each sector since the private rate of return is the same for all assets within the sector. After interasset wedges are eliminated, the intersectoral and intertemporal tax wedges remain.

In panel $\mathrm{C}$ we eliminate the intersectoral tax wedges between assets in the corporate and noncorporate sectors by equalizing social rates of return on short-lived assets in the two sectors. Similarly, we equalize 
TABLE 10

Elimination of Tax Wedges: 1985 Tax Law

1. Capital Stock in the Steady State of the Reference Case (\%)

\begin{tabular}{|c|c|c|c|c|c|}
\hline \multicolumn{2}{|c|}{ Corporate } & \multicolumn{2}{|c|}{ NONCORPORATE } & \multicolumn{2}{|c|}{ HOUSEHOLD } \\
\hline Short & Long & Short & Long & Short & Long \\
\hline .0893 & .2563 & .0185 & .2580 & .0909 & .2870 \\
\hline
\end{tabular}

2. Removal of Capital Income Tax Distortions

\begin{tabular}{llll}
\hline \hline Class of Assets & $\begin{array}{l}\text { Social Rate } \\
\text { of Return }\end{array}$ & $\begin{array}{l}\text { Effective } \\
\text { Tax Rate }\end{array}$ & ITC $+T \cdot Z^{*}$ \\
\hline
\end{tabular}

Corporate:

Short

Long

A. 1985 Tax Law

Noncorporate:

Short

Long

Household:

Short

Long

\begin{tabular}{lrl}
.0518 & .0229 & .5395 \\
.0914 & .4460 & .3257 \\
& & \\
.0433 & -.1544 & .3510 \\
.0731 & .3152 & .1409 \\
& & \\
.0503 & .1301 & .0000 \\
.0503 & .1301 & .0000 \\
\hline
\end{tabular}

B. No Within-Sector Interasset Wedges

Corporate:

Short

Long

Noncorporate:

Short

Long

Household:

Short

Long

\begin{tabular}{lll}
.0812 & .3762 & .4652 \\
.0812 & .3762 & .3942 \\
& & \\
.0711 & .2960 & .2552 \\
.0711 & .2960 & .1641 \\
& & \\
.0503 & .1301 & .0000 \\
.0503 & .1301 & .0000 \\
\hline
\end{tabular}

C. No Intersector Wedges: Business Assets

Corporate:

Short

Long

Noncorporate:

Short

Long

Household:

Short

Long

.0504

$-.0052$

.3840

.5432

.0822

.3873

.0504

.0822

.0068

.3913

.3267

.0341

.0503

.1301

.0000

.0503

.1301

.0000

D. No Intersector Wedges: All Sectors

Corporate:

Short

Long

Noncorporate:

Short

Long

.0503

.0708

$-.0062$

.2844

.5433

.0503

.0058

.2930

.4639

.0708

.1677 
TABLE 10 (Continued)

\begin{tabular}{|c|c|c|c|}
\hline Class of Assets & $\begin{array}{l}\text { Social Rate } \\
\text { of Return }\end{array}$ & $\begin{array}{l}\text { Effective } \\
\text { Tax Rate }\end{array}$ & $\mathrm{ITC}+T \cdot Z^{*}$ \\
\hline \multicolumn{4}{|l|}{ Household: } \\
\hline Short & .0503 & .1311 & -.0002 \\
\hline \multirow[t]{2}{*}{ Long } & .0708 & .3821 & -.3766 \\
\hline & \multicolumn{3}{|c|}{ E. No Tax Wedges: All Assets, Business Sector } \\
\hline \multicolumn{4}{|l|}{ Corporate: } \\
\hline Short & .0767 & .3397 & .4766 \\
\hline Long & .0767 & .3397 & .4243 \\
\hline \multicolumn{4}{|l|}{ Noncorporate: } \\
\hline Short & .0767 & .3476 & .2358 \\
\hline Long & .0767 & .3476 & .0985 \\
\hline \multicolumn{4}{|l|}{ Household: } \\
\hline Short & .0503 & .1301 & .0000 \\
\hline \multirow[t]{2}{*}{ Long } & .0503 & .1301 & .0000 \\
\hline & \multicolumn{3}{|c|}{ F. No Tax Wedges: All Assets, All Sectors } \\
\hline \multicolumn{4}{|l|}{ Corporate: } \\
\hline Short & .0667 & .2408 & .5019 \\
\hline Long & .0667 & .2408 & .4911 \\
\hline \multicolumn{4}{|l|}{ Noncorporate: } \\
\hline Short & .0667 & .2499 & .2703 \\
\hline Long & .0667 & .2499 & .2152 \\
\hline \multicolumn{4}{|l|}{ Household: } \\
\hline Short & .0667 & .3444 & -.0666 \\
\hline \multirow[t]{2}{*}{ Long } & .0667 & .3444 & -.3020 \\
\hline & \multicolumn{3}{|c|}{$\begin{array}{l}\text { G. Corporate Tax Integration: Apply Noncorporate } \\
\text { Social Rates of Return to Corporate Assets }\end{array}$} \\
\hline \multicolumn{4}{|l|}{ Corporate: } \\
\hline Short & .0433 & -.1684 & .5610 \\
\hline Long & .0731 & .3069 & .4486 \\
\hline \multicolumn{4}{|l|}{ Noncorporate: } \\
\hline Short & .0433 & -.1544 & .3510 \\
\hline Long & .0731 & .3152 & .1409 \\
\hline \multicolumn{4}{|l|}{ Household: } \\
\hline Short & .0503 & .1301 & .0000 \\
\hline \multirow[t]{2}{*}{ Long } & .0503 & .1301 & .0000 \\
\hline & \multicolumn{3}{|c|}{ H. Zero Effective Tax Rates } \\
\hline \multicolumn{4}{|l|}{ Corporate: } \\
\hline Short & .0506 & .0000 & .5425 \\
\hline Long & .0506 & .0000 & .5986 \\
\hline \multicolumn{4}{|l|}{ Noncorporate: } \\
\hline Short & .0500 & .0000 & .3279 \\
\hline Long & .0500 & .0000 & .4100 \\
\hline \multicolumn{4}{|l|}{ Household: } \\
\hline Short & .0437 & .0000 & .0265 \\
\hline Long & .0437 & .0000 & .1202 \\
\hline
\end{tabular}

Note.-Steady-state allocation of capital in the base case is used as the weights The annual rate of inflation is assumed to be 6 percent

* Equals investment tax credit plus the tax rate at the firm level times the present value of capital consumption allowances. 
social rates of return on long-lived assets. After the intersectoral tax wedges within the business sector are removed, the interasset tax wedges and intersectoral wedges between the business and household sectors still remain. In panel $\mathrm{D}$ we also eliminate the intersectoral tax wedges between business and household sectors. This approach to tax reform eliminates all the intersectoral tax wedges but creates an interasset tax wedge in the household sector where none existed before the change in tax policy. There are interasset tax wedges in the corporate and noncorporate sectors as well.

In panel $\mathrm{E}$, we eliminate both the interasset and intersectoral tax wedges in the business sector. Conceptually, the tax reforms represented in panel $\mathrm{E}$ are a combination of the reforms represented in panels $\mathrm{B}$ and $\mathrm{C}$. In panel $\mathrm{F}$, all the atemporal tax wedges are eliminated, so that the only remaining sources of tax distortions are the intertemporal tax wedges. In panel $G$, we eliminate the intersectoral tax wedges between corporate and noncorporate sectors by setting the social rates of return on corporate assets equal to the corresponding rates on noncorporate assets. The substantial reduction in tax revenue can be offset by a lump-sum tax or by proportional adjustments in the labor income tax, sales tax, or individual income tax. Finally, in panel $\mathrm{H}$, all the intertemporal tax wedges are eliminated and the social and private rates of return are equalized for all assets.

\section{Welfare Impacts}

We summarize the welfare impacts of the eight hypothetical tax reform proposals in table 11. Beginning with lump-sum tax adjustments, we find that the welfare gain from elimination of interasset tax wedges that existed under the 1985 tax law would have been $\$ 443.9$ billion. The elimination of intersectoral tax wedges between assets in the corporate and noncorporate sectors yields welfare losses instead of gains. Given Harberger's (1966) analysis of the impact of the corporate income tax, this is a rather surprising result. The elimination of a tax wedge would usually be expected to increase the efficiency of resource allocation and improve the level of economic welfare. However, the demand for capital services is much more elastic in the noncorporate sector than in the corporate sector. Equalizing the social rates of return between the corporate and noncorporate assets reduces the total demand for the business capital services.

The third change in tax policy analyzed in table 11 is the elimination of intersectoral tax wedges between household and business sectors. The results suggest that there would have been a very large potential welfare gain from this change in tax policy under the 1985 tax law. The estimated gain is $\$ 2,262.6$ billion at a 6 percent rate of in- 
TABLE 11

Welfare Effects of Tax Distortions (Billions of 1987 Dollars)

1985 Law

1. Within-sector interasset distortion:

Lump-sum tax adjustment

443.9

Labor income tax adjustment

248.1

Sales tax adjustment

168.7

Individual income tax adjustment

70.2

2. Intersector distortion: corporate and noncorporate sectors:

Lump-sum tax adjustment

Labor income tax adjustment

$-416.7$

Sales tax adjustment

$-523.8$

Individual income tax adjustment

$-715.5$

3. Intersector distortion: all sectors:

Lump-sum tax adjustment

Labor income tax adjustment

$2,156.9$

Sales tax adjustment

$2,118.6$

Individual income tax adjustment

$2,067.7$

4. No tax distortion: corporate and noncorporate sectors, all assets:

Lump-sum tax adjustment

Labor income tax adjustment

69.2

Sales tax adjustment

Individual income tax adjustment

$-169.7$

5. No tax distortion: all sectors, all assets:

Lump-sum tax adjustment

$2,663.7$

Labor income tax adjustment

$2,603.9$

Sales tax adjustment

$2,572.4$

Individual income tax adjustment

$2,547.2$

6. Corporate tax integration:

Lump-sum tax adjustment

$1,313.1$

Labor income tax adjustment

Sales tax adjustment

Individual income tax adjustment

$-274.5$

7. Consumption tax rules (zero effective tax rates):

Lump-sum tax adjustment

Labor income tax adjustment

Sales tax adjustment

Individual income tax adjustment

$2,045.4$

8. Consumption tax rules (zero effective tax rates; no sales tax on investment goods):

Lump-sum tax adjustment

Labor income tax adjustment

$1,988.0$

Sales tax adjustment

$1,722.1$

Individual income tax adjustment

$1,988.0$

Note.-Inflation is fixed at 6 percent per year.

flation. Given the substantial tax wedges between business and household assets under the 1985 tax law, this result is not surprising. For example, the intersectoral tax wedges for short-lived assets were 0.2 percent between the corporate and household sectors and -0.7 percent between the noncorporate and household sectors. The corresponding figures for long-lived assets were 4.2 percent and 2.3 percent, respectively. 
The welfare gain from eliminating the interasset and intersectoral wedges among business assets is estimated to be only $\$ 326.4$ billion under the 1985 tax law. The welfare gain from eliminating all the atemporal tax wedges in the private sector of the U.S. economy is estimated to be $\$ 2,663.7$ billion. This gain is much larger than the welfare gain resulting from elimination of interasset distortions within each sector and somewhat larger than that resulting from elimination of intersectoral tax distortions for all sectors. In view of the relative magnitude of these effects, we can attribute most of the welfare gain to elimination of intersectoral tax wedges between business and household assets.

The sixth change in tax policy we consider is the elimination of intersectoral tax wedges between assets in the corporate and noncorporate sectors. For this purpose we set social rates of return on corporate assets equal to the corresponding rates of return on noncorporate assets under the 1985 tax law. The effective tax burden on corporate assets is unambiguously reduced by this hypothetical change in tax policy. The estimated welfare gain from this change in tax policy is $\$ 1,313.1$ billion. The gain is about half of that attainable by eliminating all intersectoral tax wedges.

In the six changes in tax policy we have considered up to this point, we have focused attention on the distortionary impact of atemporal tax wedges. We next consider the elimination of intertemporal tax wedges by setting effective tax rates on all types of income from capital equal to zero. We find that the elimination of intertemporal tax wedges would have generated huge welfare gains under lumpsum tax adjustment. If sales taxes on investment goods were also abolished, the welfare gain would become even larger. With the 1985 tax law as the base case, the welfare gain from removing intertemporal tax wedges on all assets would have been $\$ 3,853.9$ billion. The elimination of the sales taxes on investment goods would have produced a gain of $\$ 4,128.1$ billion.

The magnitudes of welfare gains from elimination of the intertemporal tax wedges under distortionary tax adjustments presented in table 11 are substantially lower than those under lump-sum tax adjustment. The changes in marginal tax rates required to offset revenue losses can generate significant substitution effects. The welfare effects resulting from the elimination of intertemporal tax wedges, as given in table 11, are also sensitive to the choice among distortionary tax adjustments since the required increase in tax revenue is so large.

If a proposed tax reform is roughly revenue neutral, so that the magnitude of the required adjustment in tax revenue is small, the welfare ranking of alternative policy changes does not depend on the method for adjusting tax revenue. For a change in tax policy that involves substantial rate cuts with no compensating enhancement of 
tax revenues through base broadening, the welfare measures under the lump-sum tax adjustment can be interpreted as upper bounds of the welfare gains that can be achieved. Any realistic tax reform involving revenue adjustment through changes in distortionary taxes would result in welfare gains well below those attainable under the hypothetical lump-sum tax adjustment.

The fact that the estimated welfare gains from the elimination of the intertemporal tax wedges is in the range of $\$ 4$ trillion suggests that the potential welfare gain from replacing the current system of income taxes with consumption-based taxes would be very large indeed. However, the welfare gains would be reduced by approximately half under the more realistic assumption that revenue losses are offset by distortionary tax adjustments. These welfare gains are still impressive.

Our second conclusion is that the consequences in reductions of intertemporal tax wedges associated with consumption-based taxation must be carefully weighed against possible worsening of atemporal resource allocation as a consequence of distortions associated with increased taxes on consumption. An idealized income tax with income from household assets incorporated into the tax base would have permitted substantial reductions in tax rates on income from business assets. Such a tax would have produced greater potential gains in welfare than an idealized consumption tax, with the 1985 tax law taken as a starting point. Harberger's case for uniform tax rates on all types of capital income is strengthened by this finding, providing that uniform treatment is not limited to income from business assets.

\section{Conclusion}

The Tax Reform Act of 1986 increases the effective marginal tax burden on income from capital at any positive inflation rate. Nonetheless, the change in economic welfare relative to the 1985 tax law is positive. The 1986 tax act improves the efficiency of atemporal resource allocation sufficiently to offset the negative impact of greater effective tax rates on capital income. Higher rates of inflation result in a marked reduction in the welfare gains from the 1986 tax reform. For example, we estimate that the welfare gain is $\$ 448.4$ billion at a 6 percent rate of inflation, which amounts to 2.8 percent of U.S. private national wealth in 1987. The 1986 tax act substantially reduces interasset tax wedges within the business sector, so that potential welfare gains from further reductions are small.

An important feature of the Treasury and president's proposals is that the tax base would have been largely indexed against inflation. 
By contrast the tax burden on income from capital under the Tax Reform Act of 1986 increases significantly with the rate of inflation. While the gains from the 1986 tax act are comparable to those under the Treasury and president's proposals at inflation rates near zero, the gains under the two proposals are much greater at moderate or high rates of inflation. For example, the president's proposal would have resulted in a welfare gain of $\$ 2,452.2$ billion at a 6 percent inflation rate, which dwarfs the corresponding gain from the Tax Reform Act of 1986.

However, the largest welfare gains from tax reform would have been obtained by transferring part of the tax burden on business capital to household capital. There are obviously important political obstacles to such a transfer. Limitations on the deductibility of mortgage interest and elimination of the tax deductibility of state and local property taxes were included in the Treasury proposal. However, only very modest restrictions on the deductibility of mortgage interest survived into the 1986 tax reform legislation. The welfare gain from a tax policy that treats all forms of capital income symmetrically would have been $\$ 2,663.7$ billion at a 6 percent inflation rate. This exceeds the gain from the 1986 tax act by $\$ 2,215.3$ billion and outranks the gains from both the Treasury and president's proposals.

An alternative approach to equalizing the tax burdens between business and household assets would have been to replace the 1985 tax law with a tax system based on consumption. At a 6 percent inflation rate the welfare gain from shifting to a consumption-based tax system from a system primarily based on income would have been much larger than the gain from the Tax Reform Act of 1986. This conclusion holds for any of the alternative methods we have considered for maintaining government revenue at the same level as that under the 1985 tax law. The prospective revenue losses associated with elimination of capital income taxation would have required large increases in distortionary taxes. However, the resulting welfare losses would have been outweighed by gains in efficiency from eliminating capital income taxes.

Our overall conclusion is that indexing the U.S. tax system should receive high priority in future tax reforms. Although potential gains in welfare from the Tax Reform Act of 1986 are substantial, these gains are sharply diminished at moderate rates of inflation. The Treasury and president's proposals can provide important guidance in the practical implementation of indexing schemes. A properly indexed tax system based on income may be superior to a system based on consumption, provided that income from household assets is included in the tax base and all assets are taxed at a uniform rate. This is a second important priority for future tax reforms. 


\section{References}

$\rightarrow$ Aaron, Henry J. "Symposium on Tax Reform." J. Econ. Perspectives 1 (Summer 1987): 7-10.

$\rightarrow$ Auerbach, Alan J. "Taxation, Corporate Financial Policy and the Cost of Capital.” J. Econ. Literature 21 (September 1983): 905-40.

$\rightarrow-$. "The Tax Reform Act of 1986 and the Cost of Capital." J. Econ. Perspectives 1 (Summer 1987): 73-86.

Auerbach, Alan J., and Kotlikoff, Laurence J. Dynamic Fiscal Policy. Cambridge: Cambridge Univ. Press, 1987.

Ballard, Charles L.; Fullerton, Don; Shoven, John B.; and Whalley, John. A General Equilibrium Model for Tax Policy Evaluation. Chicago: Univ. Chicago Press (for NBER), 1985.

Ballentine, J. Gregory. "Comment." In The Effects of Taxation on Capital Accumulation, edited by Martin S. Feldstein. Chicago: Univ. Chicago Press (for NBER), 1987.

Birnbaum, Jeffrey H., and Murray, Alan S. Showdown at Gucci Gulch: Lawmakers, Lobbyists, and the Unlikely Triumph of Tax Reform. New York: Random House, 1987.

Bradford, David F. Untangling the Income Tax. Cambridge, Mass.: Harvard Univ. Press, 1986.

$\rightarrow$ Chamley, Christophe. "The Welfare Cost of Capital Income Taxation in a Growing Economy." J.P.E. 89 (June 1981): 468-96.

Cilke, James M., and Wyscarver, Roy A. "The Treasury Individual Income Tax Simulation Model." In Compendium of Tax Research 1987, by the U.S. Department of the Treasury. Washington: Government Printing Office, 1987.

Fullerton, Don; Gillette, Robert; and Mackie, James. "Investment Incentives under the Tax Reform Act of 1986." In Compendium of Tax Research 1987, by the U.S. Department of the Treasury. Washington: Government Printing Office, 1987.

Fullerton, Don; Henderson, Yolanda K.; and Mackie, James. "Investment Allocation and Growth under the Tax Reform Act of 1986." In Compendium of Tax Research 1987, by the U.S. Department of the Treasury. Washington: Government Printing Office, 1987.

Gordon, Roger H.; Hines, James R., Jr.; and Summers, Lawrence H. "Notes on the Tax Treatment of Structures." In The Effects of Taxation on Capital Accumulation, edited by Martin S. Feldstein. Chicago: Univ. Chicago Press (for NBER), 1987.

$\rightarrow$ Goulder, Lawrence H., and Summers, Lawrence H. "Tax Policy, Asset Prices, and Growth: A General Equilibrium Analysis." J. Public Econ. 38 (April 1989): 265-96.

Gravelle, Jane G. "Tax Policy and Rental Housing: An Economic Analysis." Manuscript. Washington: Congressional Res. Serv., 1987.

$\rightarrow$ Gravelle, Jane G., and Kotlikoff, Laurence J. "The Incidence and Efficiency Costs of Corporate Taxation When Corporate and Noncorporate Firms Produce the Same Good." J.P.E. 97 (August 1989): 749-80.

Hall, Robert E. "The Dynamic Effects of Fiscal Policy in an Economy with Foresight." Rev. Econ. Studies 38 (April 1971): 229-44.

Hall, Robert E., and Rabushka, Alvin. Low Tax, Simple Tax, Flat Tax. New York: McGraw-Hill, 1983.

$\rightarrow$ Harberger, Arnold C. "The Incidence of the Corporation Income Tax." J.P.E. 70 (June 1962): 215-40.

- "Efficiency Effects of Taxes on Income from Capital." In Effects of 
Corporation Income Tax, edited by Marian Krzyzaniak. Detroit: Wayne State Univ. Press, 1966.

Hausman, Jerry A. "Labor Supply." In How Taxes Affect Economic Behavior, edited by Henry J. Aaron and Joseph A. Pechman. Washington: Brookings Inst., 1981.

- "Taxes and Labor Supply." In Handbook of Public Economics, vol. 1, edited by Alan J. Auerbach and Martin S. Feldstein. Amsterdam: NorthHolland, 1985.

$\rightarrow$ Hausman, Jerry A., and Poterba, James M. "Household Behavior and the Tax Reform Act of 1986." J. Econ. Perspectives 1 (Summer 1987): 101-19.

Joint Committee on Taxation. Summary of Conference Agreement on H.R. 3838 (Tax Reform Act of 1986). Washington: Government Printing Office, 1986.

$\rightarrow$ Jorgenson, Dale W., and Yun, Kun-Young. "The Efficiency of Capital Allocation." Scandinavian J. Econ. 88, no. 1 (1986): 85-107. (a)

$\rightarrow$ "Tax Policy and Capital Allocation." Scandinavian J. Econ. 88, no. 2 (1986): 355-77. (b)

$\rightarrow$ Judd, Kenneth L. "The Welfare Cost of Factor Taxation in a PerfectForesight Model." J.P.E. 95 (August 1987): 675-709.

King, Mervyn A., and Fullerton, Don. The Taxation of Income from Capital: A Comparative Study of the United States, the United Kingdom, Sweden, and West Germany. Chicago: Univ. Chicago Press (for NBER), 1984.

$\rightarrow$ McLure, Charles E., Jr., and Zodrow, George R. "Treasury I and the Tax Reform Act of 1986: The Economics and Politics of Tax Reform." J. Econ. Perspectives 1 (Summer 1987): 37-58.

$\rightarrow$ Musgrave, Richard A. "Short of Euphoria." J. Econ. Perspectives 1 (Summer 1987): 59-71.

$\rightarrow$ Pechman, Joseph A. "Tax Reform: Theory and Practice." J. Econ. Perspectives 1 (Summer 1987): 11-28.

$\rightarrow$ Poterba, James M., and Summers, Lawrence H. "Dividend Taxes, Investment, and 'Q.'” J. Public Econ. 22 (November 1983): 135-67.

Sandmo, Agnar. "The Effects of Taxation on Savings and Risk Taking." In Handbook of Public Economics, vol. 1, edited by Alan J. Auerbach and Martin S. Feldstein. Amsterdam: North-Holland, 1985.

Sinn, Hans-Werner. Capital Income Taxation and Resource Allocation. Amsterdam: North-Holland, 1987.

Summers, Lawrence H. "The Nonadjustment of Nominal Interest Rates: A Study of the Fisher Effect." In Macroeconomics, Prices, and Quantities: Essays in Memory of Arthur M. Okun, edited by James Tobin. Washington: Brookings Inst., 1983.

$\longrightarrow \rightarrow-$ " The After-Tax Rate of Return Affects Private Savings." A.E.R. Papers and Proc. 74 (May 1984): 249-53.

U.S. Department of the Treasury. Blueprints for Basic Tax Reform. Washington: Government Printing Office, 1977.

- Tax Reform for Fairness, Simplicity, and Economic Growth. 3 vols. Washington: Government Printing Office, 1984.

. The President's Tax Proposals to the Congress for Fairness, Growth, and Simplicity. Washington: Government Printing Office, 1985.

. Compendium of Tax Research 1987. Washington: Government Printing Office, 1987.

Whalley, John. "Lessons from General Equilibrium Models." In Uneasy Compromise: Problems of a Hybrid Income-Consumption Tax, edited by Henry J. Aaron, Harvey Galper, and Joseph A. Pechman. Washington: Brookings Inst., 1988. 